Jerzy Żmudziński

\title{
Wystrój malarski kaplic kościoła Kamedułów na Bielanach i jego znaczenie dla sztuki Krakowa 1. połowy XVII w. (kaplice Królewska i Delpacowska)
}

Ogromne znaczenie eremu bielańskiego dla dziejów sztuki polskiej czasów przełomu manieryzmu i baroku jest od dawna należycie docenione. Dotyczy to jednak w pierwszym rzędzie architektury i jej wystroju (stiuków), a w znacznie mniejszym stopniu malarstwa. Wielokrotnie przywoływano w opracowaniach sztuki polskiej 1. połowy XVII w. malarski wystrój kaplic bielańskich, najczęściej jednak ograniczano się do stwierdzenia, że część tej dekoracji jest dziełem weneckiego malarza Tomasza Dolabelli i jego warsztatu (wystrój malarski kaplic Królewskiej i Delpacowskiej) i ilustruje proces niejako „degradacji” tego artysty, który przybywszy do Polski w ostatnich latach XVI w. z czasem zagubił osiągnięcia wielkiej szkoły weneckiej doby manieryzmu, zaniżył standardy wykonywanych dzieł i uległ swoistej „sarmatyzacji”, dostosowując się do gustów i oczekiwań miejscowych odbiorców. W malowidłach dwóch najważniejszych kaplic bielańskiego kościoła widziano dzieła jego samego, jego uczniów i naśladowców ${ }^{1}$. Teza o „sarmatyzacji” i obniżeniu się poziomu twórczości Dolabelli niedawno poddana została krytycznej analizie, przy okazji której przywołano i w pewien sposób „zrehabilitowano” źródłowo

1 Jako pierwszy szerzej omówił tę kwestię M. Skrudlik, Tomasz Dolabella, jego życie i dzieła. Ustęp $z$ dziejów malarstwa XVII stulecia w Polsce, „Rocznik Krakowski”, T. 16, 1914, s. 138 i 140-141 . Badacz ten uważał zdecydowaną większość obrazów z kaplic Królewskiej i Delpacowskiej za dzieła uczniów artysty, natomiast w dekoracji malarskiej pozostałych czterech kaplic otwartych do nawy głównej nie dostrzegał już wpływów Dolabelli, wskazując na inną genezę artystyczną obrazów na sklepieniach tych kaplic (idąc za starszą literaturą dopuszczał w tym przypadku autorstwo Jana Chryzostoma Proszowskiego - zob. tamże, s. 146). Poglądy Skrudlika znalazły swoje odbicie w późniejszych publikacjach, choć nie wszyscy badacze oceniali malowidła bielańskie tak surowo jak Skrudlik. 
potwierdzone dzieła tego artysty z kaplicy Królewskiej². W prezentowanym tu studium pojawia się okazja, żeby kwestię tę poruszyć w nieco innym kontekście. Warto bowiem spróbować odpowiedzieć na pytanie, co tak naprawdę sprawia, że właściwe rozpoznanie i analiza zabytków malarstwa nowożytnego z kaplic kościoła Kamedułów na Bielanach może mieć tak istotne znaczenie dla badań nad sztuką Krakowa w czasach baroku. Czy badania te będą zawsze krążyć wokół problemu ewolucji maniery tylko jednego warsztatu - znanego weneckiego mistrza czynnego tak długo w naszym kraju?

W dotychczasowych publikacjach najwięcej miejsca poświęcono architekturze kościoła klasztornego. Wielu uczonych, począwszy od końca XIX w., usiłowało rozstrzygnąć zarówno problem autorstwa świątyni, jak i rozwarstwienia faz jej budowy. Choć kilka kwestii pozostaje niewyjaśnionych, można obecnie stwierdzić, odwołując się do badań najbardziej w tej materii kompetentnego Adama Małkiewicza ${ }^{3}$, iż pierwotne projekty zarówno całego eremu, jak i świątyni, przywiezione $\mathrm{z}$ Włoch, reprezentowały rozwiązania akceptowane $\mathrm{w}$ tym czasie przez kamedułów, którzy oprócz powielania rygorystycznie pojmowanego rozplanowania właściwego eremu przeciwstawiali się zbyt rozbudowanej architekturze towarzyszącego mu kościoła. Zwykle był on budowlą uproszczoną i pozbawioną ozdób, jednoprzestrzenną, z jednym tylko ołtarzem i dwoma kaplicami w pobliżu wejścia, uzupełnioną o zakrystię i kapitularz po bokach części prezbiterialnej, a także o dzwonnicę dostawioną do świątyni w połowie jej długości. Nie wiemy, jak w szczegółach wyglądał na Bielanach proces odchodzenia

2 Zob. J. Żmudziński, O potrzebie badań nad twórczościa Tomasza Dolabelli. Ze studiów nad obrazami w kościele Mariackim i kościele Kamedułów na Bielanach w Krakowie, „Folia Historiae Artium. Seria Nova”, vol. 12, 2009, s. 123-144.

3 Por. przede wszystkim: A. Małkiewicz, Zespół architektoniczny na Bielanach pod Krakowem (1605-1630), Zeszyty Naukowe Uniwersytetu Jagiellońskiego. Prace 45, Prace z Historii Sztuki, Z. 1, 1962, s. 143-186, il. 1-32 na nlb. tabl.; tenże, Z historycznej i artystycznej problematyki kościoła kamedułów na Bielanach pod Krakowem, Zeszyty Naukowe Uniwersytetu Jagiellońskiego CCCII, Prace z Historii Sztuki, Z. 10, 1972, s. 83-108, il. 1-12 na nlb. tabl.; z nowszych publikacji tego uczonego, przedstawiających wyniki badań w sposób bardziej syntetyczny, zob.: tenże, Barokowa architektura sakralna $w$ Krakowie, [w:] Ars Vetus et Nova, t. 2; A. Małkiewicz, Theoria und praxis. Studia z dziejów sztuki nowożytnej i jej teorii, Kraków 2000, s. 154, 159, 163-166; tenże, Rzym a barokowa architektura Krakowa, „Rocznik Krakowski”, T. 69, 2003, s. 49-53. Z opracowań autorstwa innych badaczy największe znaczenie dla problematyki architektury zespołu bielańskiego ma rozprawa polemiczna stosunku wobec niektórych stwierdzeń Małkiewicza, zawartych w jego wczesnej publikacji z 1962 r.; W. Kret, Problematyka artystyczna kościoła OO. Kamedułów na Bielanach pod Krakowem. Geneza - charakterystyka - oddziaływanie, „Kwartalnik Architektury i Urbanistyki", T. 12, 1967, Z. 3-4, s. 23-55. 
od tego modelu w stronę większego skomplikowania przestrzennego i ozdobności, wymuszonych przez bogatego fundatora, marszałka Mikołaja Wolskiego. Kościół wznoszono od 1609 r. w dwóch fazach rozdzielonych katastrofą budowlaną w 1617 r. W drugiej fazie zatrudniono wybitnego lombardzkiego architekta czynnego także w Czechach, Andrea Spezzę, którego uznać można co najmniej za twórcę dwuwieżowej fasady. Jej ukończenie w 1630 r. oznaczało zamknięcie prac budowlanych przy kościele, który poświęcono w $1642 \mathrm{r}$.

Kościół bielański łamie zasady budownictwa kamedulskiego. Ale za to dzięki determinacji hojnego fundatora, wykorzystaniu włoskich planów, udziałowi znakomitego architekta i starannemu opracowaniu detalu świątynia ta klasą artystyczną dorównuje najlepszym rzymskim i północnowłoskim realizacjom z przełomu XVI i XVII w., łącząc w sobie w twórczy sposób cechy manierystyczne i barokowe. Trudno tu pominąć jej walory: doskonałość założenia z dojściem przez kolejne bramy i rozległy dziedziniec poprzedzający szeroko rozłożoną dwuwieżową fasadę - jedną z pierwszych w pełni nowożytnych elewacji tego rodzaju w Europie Środkowej, a następnie monumentalny wyraz wyjątkowo szerokiej głównej nawy świątyni, do której przylegają ciągi płytkich kaplic. To właśnie w oprawie tej architektury spotykamy liczne dzieła nowożytnego malarstwa ściennego i sztalugowego.

Nie można w tym miejscu pominąć specyfiki stanu badań nad wystrojem wnętrza świątyni. Badania te, niezbyt obfite, warunkował w dużej mierze stopień wyzyskania archiwaliów konwentu bielańskiego. W nieuporządkowanym w nowoczesny sposób archiwum klasztoru ${ }^{4}$ oraz w nielicznych rękopisach, które

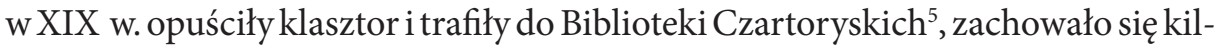
kadziesiąt umów i rachunków dotyczących prac malarskich. W końcu XIX i w początkach XX w. w drobnej części wyzyskali je: historyk-amator Ludwik Zarewicz ${ }^{6}$ oraz Jan Ptaśnik ${ }^{7}$. Potem, w początkach lat 70. XX w., archiwum szczegółowo

4 Nie dysponujemy żadnym opracowaniem - historycznym ani inwentarzowym - archiwum bielańskiego, które po II wojnie światowej długo uchodziło za zaginione czy w każdym razie całkowicie zdewastowane (por. A. Małkiewicz, Zespół..., dz. cyt. przypis 8 na s. 178), a jako pierwszy uzyskał do niego dostęp na początku lat 70. XX w. Jacek Gajewski (zob. dalej).

5 Bardzo ogólna charakterystyka tego zespołu zob. Zbiory rękopisów w bibliotekach i muzeach $w$ Polsce. Wydanie drugie poprawione i rozszerzone, oprac. D. Kamolowa przy współudziale T. Sieniatyckiej, seria „Biblioteka Narodowa. Zakład Rękopisów. Zbiory Rękopisów w Polsce”, t. 1, Warszawa 2003, s. 166.

6 L. Zarewicz, Zakon Kamedułów, jego fundacje i dziejowe wspomnienia w Polsce i Litwie, przeważnie według źródeł rękopiśmiennych archiwum OO. Kamedułów w Bielanach przy Krakowie, Kraków 1871.

7 J. Ptaśnik, [komunikat w:] „Sprawozdania Komisji do Badania Historii Sztuki w Polsce”, T. 9, z. I i II, 1913, szp. LXVII-LXVIII. 
eksplorował warszawski badacz Jacek Gajewski, który przygotował rozprawę dotyczącą dziejów wyposażenia i wystroju konwentu, opracowanych w oparciu o źródła pisane ${ }^{8}$. Jacek Gajewski opublikował na temat kilka szczegółowych artykułów i od 35 lat konsekwentnie zapowiada - bez żadnego skutku - wydanie całościowego opracowania na ten temat ${ }^{9}$. W międzyczasie jednak, wobec trudności w bieżącym korzystaniu $\mathrm{z}$ archiwum ${ }^{10}$, pozostający w maszynopisie tekst Gajewskiego, zawierający wypisy z archiwum, stał się głównym źródłem informacji o dziejach świątyni. Najwyraźniej konwent bielański nie ma szczęścia, jeśli chodzi o badania podstawowe, gdyż w maszynopisie pozostaje także tekst Katalogu zabytków sztuki w Polsce, autorstwa Jacka Gajewskiego, Piotra Pałamarza i Jerzego Petrusa, przygotowany w latach 70 . XX w. ${ }^{11}$. Poza wyjątkami - do których, odnośnie XVII w., należy postawienie przez Janinę Dzik tezy o autor-

8 Była to praca magisterska przygotowana w 1972 r. w Instytucie Historii Sztuki Uniwersytetu Warszawskiego, pisana pod kierunkiem Mariusza Karpowicza, zatytułowana Wystrój kościoła OO. Kamedułów na Bielanach pod Krakowem w świetle materiałów archiwalnych; autor kopię tej pracy przekazał klasztorowi na Bielanach (w chwili obecnej dostępna jest jedynie jej druga część zawierająca przede wszystkim Katalog artystów i rzemieślników pracujących na Bielanach, wraz z wypisami źródłowymi obejmującymi kontrakty i rachunki, s. 1-358).

9 Trzeba tu przywołać tylko jego najważniejsze prace - te, które dotyczą w różnym zakresie malarskiego wystroju konwentu: J. Gajewski, Kościół i klasztor kamedułów na Bielanach pod Krakowem $w$ świetle materiałów archiwalnych (Streszczenie referatu wygłoszonego na zebraniu naukowym Oddziału Warszawskiego SHS w dniu 6 czerwca 1973 r.), „Biuletyn Historii Sztuki”, R. 38, 1976, nr 4, s. 374-377 (tu w przypisie na s. 377 pierwsza zapowiedź publikacji całego materiału) - najważniejsza praca zawierająca szereg informacji, pozbawiona jednak przypisów źródłowych; tenże, Prace Jana Eliasza Hoffmanna dla zakonu Kamedułów, „Biuletyn Historii Sztuki”, R. 40, 1978, nr 3, przypisy 11 na s. 261 i 21 na s. 263 (informacje na temat pierwotnego ołtarza głównego w kaplicy Delpacowskiej z lat 40. XVII w. i obrazu w nim umieszczonego); tenże, Prace Antoniego Frączkiewicza dla zakonu Kamedułów. Ze studiów nad rzeźba połowy XVIII w. w Małopolsce, „Biuletyn Historii Sztuki”, R. 41, 1979, nr 4, s. 363 i 365 oraz przypis 5 na s. 363 (informacje dotyczące okoliczności fundacji kaplicy Królewskiej, zasadniczego przesłania jej programu oraz pierwotnego ołtarza z lat 1635-1636), także s. 368-369 (obraz ołtarzowy z XVIII w.).

${ }_{10}$ W czasie prac konserwatorskich prowadzonych we wnętrzu kościoła bielańskiego od 1993 r., obejmujących kapitularz, lokalności przy zakrystii i kaplice boczne kościoła, archiwum - choć nieuporządkowane - było jednak dostępne i historycy sztuki przygotowujący dokumentację historyczną tych prac (Stanisław Sławiński, a od 1994 r. autor niniejszego artykułu) mogli korzystać z oryginalnych dokumentów. Po 2000 r. archiwum zostało zamknięte aż do czasu zakończenia niezbędnych prac porządkowych (dostępne są jedynie inwentarze z XIX w.).

11 J. Gajewski, P. Pałamarz, J. Petrus, Kościół p.w. Wniebowzięcia N. P. Marii i klasztor kamedułów na Bielanach, Katalog zabytków sztuki w Polsce, mps w zbiorach Instytutu Sztuki Polskiej Akademii Nauk w Warszawie. 
stwie Franciszka Lekszyckiego odnośnie obrazu Św. Sebastiana ${ }^{12}$, opublikowanie uwag dotyczących przechowywanego w kościele Portretu Mikołaja Wolskiego ${ }^{13}$, wreszcie odkrycie sygnowanego obrazu (Św. Jan Chrzciciel nauczający) z 1689 r., autorstwa Jana Reisnera, wykształconego w Rzymie wybitnego malarza nadwornego Jana III Sobieskiego ${ }^{14}$ - nie były także udostępnione ustalenia powstałe równolegle z pracami konserwatorskimi prowadzonymi w latach 90. zeszłego stulecia. Różne spostrzeżenia pozostają ukryte w dokumentacjach dostępnych w archiwach służb konserwatorskich. Natomiast w ostatnich latach Beata Frey-Stecowa poczyniła kilka ciekawych uwag na temat graficznych pierwowzorów niektórych obrazów zachowanych w obrębie zespołu bielańskiego ${ }^{15}$. Z kolei dzieła malarstwa z XVIII stulecia zachowane na Bielanach prawie nie budziły zainteresowania badaczy ${ }^{16}$.

Trudno się więc dziwić, że omówienia dzieł malarstwa w świątyni kamedułów skupiają się właściwie na pracach dwóch twórców. Stałym zainteresowaniem cieszy się osoba włoskiego malarza i zarazem kameduły, o. Wenantego z Subiaco (około 1579-1659), który jako dojrzały artysta zdecydował się wstą-

12 J. Dzik, Franciszek Lekszycki, malarz religijny baroku, Kalwaria Zebrzydowska 1998, poz. kat. 14 na s. 131-132 (tu zestawienie wcześniejszej literatury z przywołaniem ważnej pracy Mariana Korneckiego), il. 18.

13 Narodziny stolicy. Warszawa w latach 1596-1668, [katalog wystawy], Zamek Królewski w Warszawie, 9 września-31 grudnia 1996, Warszawa 1996, poz. kat. XI 3 na s. 351-352 (tu zestawienie wcześniejszej literatury; notę opracował P. Mrozowski), il. $52 \mathrm{w}$ albumie ilustracji barwnych.

${ }^{14}$ J. Żmudziński, Warszawski malarz na krakowskich Bielanach, „Spotkania z Zabytkami”, R. 24, 2000, nr 8 (162), s. 11; tenże, Nowe wiadomości o obrazach malarza Jana Reisnera, [w:] Kultura artystyczna Warszawy XVII-XXI w. Studia, red. Z. Michalczyk, A. Pieńkos, M. Wardzyński, Warszawa 2010, materiały z sesji zorganizowanej w dniach 11-13 grudnia 2007 r. przez Instytut Historii Sztuki Uniwersytetu Warszawskiego, w druku.

15 B. Frey-Stecowa, $Z$ dalszych badań nad oddziaływaniem grafiki na wystrój kościoła św. Krzyża w Krakowie, [w:] Studia z dziejów kościoła św. Krzyża w Krakowie, cz. III, red. ks. Z. Kliś i G. Lichończak-Nurek, Kraków 1999, przypis 11 na s. 279; taż, Geneza scen pasyjnych na kolumnie zwanej Boża Męka przed klasztorem Kamedułów na Bielanach, czyli o popularności rycin ilustrujących „Evangelicae Historiae Imagines Hieronymusa Natalisa”, „Historica Cracoviensa”, vol. 11, 2005, s. 136 (tu uwagi na temat graficznych wzorów dekoracji malarskiej kapitularza - il. 2, 3, 5, 7 na s. $142-145)$.

16 Jedynie obraz w ołtarzu kaplicy Królewskiej - przedstawienie Św. Brunona (Bonifacego), Władysława i Benedykta, wykonane około 1738 r. lub nieco później - budził pewne zainteresowanie badaczy, którzy przypisywali go Szymonowi Czechowiczowi, Tadeuszowi Kuntzemu lub Łukaszowi Orłowskiemu - zob. J. Gajewski, Prace Antoniego Frączkiewicza..., dz. cyt., s. 369; D. Dolański, Tadeusz Kuntze - malarz z Zielonej Góry (1733-1793), Zielona Góra 1993, poz. kat. 30 na s. 72. 
pić do zakonu w 1618 r., a w 1624 r. wysłany został do Polski, gdzie przebywał aż do 1633 r., będąc m.in. w latach 1627-1630 przeorem bielańskim. Ten konserwatywny przedstawiciel nurtu caravaggionizmu w malarstwie włoskim przyczynił się do ozdoby kościoła bielańskiego, wykonując (zniszczone pożarem w 1814 r.) obrazy w ołtarzu głównym i chórze zakonnym oraz pojedyncze dzieła w kapitularzu, zakrystii i przyległej doń małej kaplicy. Twórczość Wenantego ostatnio stała się przedmiotem badań Lucilli Conigliello ${ }^{17}$, a na gruncie polskim aktualny stan wiedzy podsumował Adam Małkiewicz ${ }^{18}$. Znamienne, że interesująca twórczość Wenantego nie wywarła wpływu na dzieła miejscowego środowiska, skądinąd w początkach XVII w. otwartego na wpływy malarstwa włoskiego, głównie weneckiego.

Obok danych o dziełach o. Wenantego w literaturze naukowej w szerszym kontekście wykorzystana została jeszcze tylko wzmianka opublikowana przez Jana Ptaśnika w 1913 r., mówiąca o wykonaniu przez Tomasza Dolabellę malowideł w kaplicy Królewskiej ${ }^{19}$. Informacja ta była podstawą do przypisania Dolabelli także wystroju drugiej najważniejszej kaplicy świątyni kamedułów - poświęconej św. Romualdowi. Do tego zagadnienia przyjdzie nam jeszcze powrócić.

Tymczasem ranga bielańskiego zespołu dzieł malarstwa jest wyższa, niż to wynika ze skromnego stanu badań. Jeśli porównać świątynię kamedułów z kościołami krakowskimi, to stwierdzić trzeba, że chyba nigdzie dzieła malarstwa ściennego i sztalugowego rozpatrywane łącznie nie odgrywają tak wiodącej roli w wystroju wnętrza. Są oczywiście w Krakowie, np. w klasztorze dominikanów, zbiory bogatsze ilościowo niż bielański. Jednak w zespołach tych nielicznie zachowane obrazy pochodzące z wystroju ukształtowanego w XVII w. zostały $\mathrm{w}$ znacznym stopniu przemieszczone $\mathrm{z}$ miejsc swego pierwotnego przeznaczenia, ale także pomieszane z dziełami nabytymi wtórnie. Na Bielanach jest stosunkowo niewiele obrazów nie powiązanych na stałe z konkretnym miejscem, większość od początku stanowiła integralną część z góry planowanego wystroju. Tworzą więc one zwarty zespół dzieł zdobiących kaplice boczne kościoła oraz inne pomieszczenia wbudowane w bryłę świątyni: kapitularz od północnej stro-

17 Da Antiveduto della Gramatica a Venanzio l'eremita. Nuovi dipinti caravaggeschi a Camaldoli, a cura L. Conigliello, [katalog wystawy], Poppi, Castello dei Conti Guidi, 5 agosto - 31 ottobre 1995, Firenze 1995.

18 A. Małkiewicz, Twórczość malarza-kameduły o. Wenantego z Subiaco w świetle najnowszych badań, „Folia Historica Cracoviensa”, vol. 11, 2005, s. 117-132.

19 J. Ptaśnik, art. cyt., szp. LXVII. 
ny prezbiterium i zakrystię z małą kapliczką od południa. Nawa główna kościoła w założeniu miała pozostać niemal pusta, a wyposażenie prezbiterium spłonęło w 1814 r.

Szczególnie bogaty jest wystrój malarski sześciu kaplic usytuowanych po bokach nawy głównej. O ile np. w kapitularzu obrazy sztalugowe są jakby osobno osadzone w ścianach i sklepieniach, które poza tym maja własną dekorację, stwarzającą dające się wyraźnie określić tło, o tyle w kaplicach bocznych obrazy w ramach wypełniają szczelnie powierzchnie ścian tarczowych i ościeża wielkich arkad do nawy głównej, dostosowując swoją formę do kształtu ścian przerywanych otworami drzwiowymi (fot. 1). Dekoracja malarska znajdująca się bezpośrednio na ścianach (poza sklepieniami) ograniczona jest do minimum. Obrazy sztalugowe stanowią w ten sposób decydujący element składowy całościowego systemu dekoracji dominującego w wystroju wnętrz, które projektowane i wyposażone były jako jednolite, odrębne „jednostki” przestrzenne. Jedną całość z dziełami malarstwa sztalugowego tworzą w nich: pokryte stiukiem sklepienia z marginalną dekoracją malarską otaczającą pola wypełnione przez również malowane bezpośrednio na tynku sceny figuralne (fot. 12), dekoracja malarska na nielicznych odsłoniętych powierzchniach ścian poniżej partii sklepień, ołtarze z obrazami, portale, balustrady i posadzki. Typ „boazeryjnego” malarstwa, zastosowanego w kaplicach, wywodzi się ze sztuki włoskiej, szczególnie popularny jest we wnętrzach kościołów weneckich, a w Krakowie w tak wczesnej i konsekwentnej formie obecnie zachował się jedynie na Bielanach ${ }^{20}$.

Spójność systemu, dominacja malarstwa i wczesne datowanie to nie jedyne walory tej dekoracji. Godna podkreślenia jest ciągłość pracy nad tym wystrojem. Począwszy od lat 30. aż do lat 90. XVII stulecia w krótkich odstępach czasu fundowano - czyniły to m.in. osoby świeckie, w tym aż trzykrotnie Rafał del Pace - kolejne elementy wystroju. Najwcześniej powstawała dekoracja sklepień, później wznoszono ołtarze z obrazami, wreszcie wykonywano polichromię ścian i sklepień oraz obrazy sztalugowe. W niektórych przypadkach polichromię ścian uzupełniano drewnianymi ramami, aby imitować obrazy na płótnie i nie rozbijać jednolitego efektu systemu dekoracyjnego kaplic. Naturalnie nie wszystko dotrwało w tym zespole nie zmienione. Nie zachowały

$20 \mathrm{Na}$ temat tego sposobu dekoracji we wnętrzach krakowskich kościołów w początkach XVII w. zob. J. Żmudziński, Kaplica Kaufmanów w wieży południowej kościoła Mariackiego w Krakowie (XVI-XVII w.). Na granicy przestrzeni publicznej i prywatnej miasta, [w:] Mecenat artystyczny a oblicze miasta. Materiały LVI Ogólnopolskiej Sesji Naukowej Stowarzyszenia Historyków Sztuki, Kraków 8-10 XI 2007, Kraków 2008, s. 53-54. 
się pierwotne ołtarze - w kaplicach Królewskiej i Delpacowskiej zastąpiły je już w latach 30. XVIII w. retabula późnobarokowe, zaś w pozostałych czterech przypadkach w 2. połowie XIX w. wystawiono nowe ołtarze, w ogólnych zarysach naśladujące poprzednie, wykorzystując przy tym część ornamentów i rzeźb. Dwa spośród sześciu głównych płócien ołtarzowych zamieniono w XVIII w. na nowe obrazy (w kaplicach Królewskiej i świętych Piotra i Pawła). Z początków XVIII stulecia pochodzą też pełniące marginalną rolę w wystroju kaplicy Delpacowskiej przedstawienia pustelników w dolnej części ścian (fot. 18) ${ }^{21}$ oraz - tu kwestia datowania rodzi pewne wątpliwości - obrazy znajdujące się w analogicznym miejscu w kaplicy Królewskiej (fot. 11) ${ }^{22}$. Zniszczały też pojedyncze obrazy z XVII w. ze ścian i ościeży arkad kaplic, zastąpione później przez inne kompozycje. Jednak przetrwała niemal w całości główna część malarskiej dekoracji na sklepieniach, ścianach tarczowych i ościeżach arkad.

Dzięki zapisom $\mathrm{z}$ archiwum bielańskiego i sygnaturom znamy niektórych twórców tej dekoracji ${ }^{23}$. Jeśli pominąć pojedyncze anonimowe dzieła, kompo-

${ }^{21}$ Cykl scen tworzy jednolity stylistycznie zespół (o czym dobitnie przekonują identycznie ukształtowane tła pejzażowe), a w obrębie dwóch obrazów z cyklu pojawiają się bogate malowane obramienia z szerokiej wstęgi łączącej się z wicią, które można w warunkach krakowskich datować najwcześniej na początek XVIII w. (w niepublikowanym tekście Katalogu zabytków... Zob. J. Gajewski, P. Pałamarz, J. Petrus, Kościół p.w. Wniebowzięcia..., dz. cyt., s. 20 - polichromia na boazerii w kaplicy Delpacowskiej datowana jest ogólnie na XVIII w.)

22 Zachowane rachunki odnoszące się do wystroju kaplicy Królewskiej (zob. J. Ptaśnik, art. cyt., szp. LXVIII) informują, że w 1633 r. brakowało jeszcze m.in. „opaski marmurowey [...] do koła” kaplicy - planowano ją wykonać z czarnego marmuru. Obecnie dolne partie ścian przykrywa drewniana, polichromowana boazeria podzielona, tak jak w kaplicy Delpacowskiej, na dwie strefy - niższa imituje wielobarwną okładzinę marmurową, wyższa zawiera serię scen odnoszących się do św. Brunona (Bonifacego) i jego misji oraz dołączone do tego cyklu przedstawienie Stygmatyzacji św. Franciszka (o programie kaplicy będzie mowa dalej). Niektóre elementy tych scen mają wyraźną genezę sięgającą malarstwa 1. połowy XVII w. (cześć pejzaży w tłach z motywami górskimi, motywy architektoniczne w scenie Wysyłania św. Brunona na misję przez papieża), cechy stylowe innych elementów w tych samych obrazach (grupa postaci w scenie Wysytania...) lub całych kompozycji wskazują najpewniej na przełom XVII i XVIII w. (lub początek XVIII w.). Dla rozstrzygnięcia kwestii datowania obrazów na boazerii kaplicy Królewskiej potrzebna jest odrębna, szczegółowa analiza (można przyjąć, że możliwa jest w początkach XVIII w. pewna archaizacja stylowa), natomiast pewne jest, że nie należą one do najstarszego wystroju kaplicy z lat 30. XVII w. (w cytowanym Katalogu zabytków... zob. J. Gajewski, P. Pałamarz, J. Petrus, Kościót p.w. Wniebowzięcia..., dz. cyt., s. 18 - obrazy te datowane są na XVIII w. i określono je, może zbyt pochopnie, jako „silnie przemalowane”).

${ }^{23}$ Zaprezentowane tu atrybucje oparte są na badaniach własnych autora, ustaleniach Jacka Gajewskiego przedstawionych $\mathrm{w}$ jego publikacjach i danych zaczerpniętych $\mathrm{z}$ dokumentacji 
zycje Venantego z Subiaco (jego obrazy ołtarzowe zachowały się w kapitularzu oraz kaplicy św. Józefa położonej obok zakrystii), a także dwie najważniejsze kaplice, Królewską i Delpacowską (o których mowa będzie dalej), stwierdzić można, że dla Bielan pracowali w 2. połowie XVII w. m.in.: Paweł Kotlarz (w kaplicy śś. Piotra i Pawła), zapewne artysta krakowski, następnie Piotr Brygierski, artysta z Cieszyna czynny w Krakowie (kaplice Michała Archanioła, św. Anny i śś. Janów), znany tylko z imienia malarz Mikołaj z Warszawy (malowidła sklepienia kaplicy śś. Janów), wspomniany Jan Reisner z Warszawy (obraz ołtarzowy w tejże kaplicy). Chcąc poszerzyć tę listę o twórców dzieł malarskich w kapitularzu i w kaplicach pod wieżami, wymienić trzeba jeszcze krakowskiego malarza Jana Koya (w kapitularzu), hipotetycznie bernardyńskiego artysta Franciszka Lekszyckiego (obraz Św. Sebastiana w kaplicy tegoż świętego pod wieżą) oraz artystów z XVIII w. - działającego w Krakowie Franciszka Ignacego Molitora (autora obrazu Św. Jana Nepomucena z 1759 r. w zwieńczeniu ołtarza w kaplicy św. Sebastiana) i wybitnych, choć nie ustalonych jednoznacznie twórców obrazów ołtarzowych z 2. ćwierci XVIII w. w kaplicach Królewskiej i śś. Piotra i Pawła. Dalsze badania z całą pewnością pozwolą wyłonić wśród wykonawców dekoracji malarskiej na Bielanach kolejnych artystów.

Mamy więc do czynienia z niepospolitą galerią dzieł malarstwa krakowskiego, głównie z XVII w., zachowanych in situ, na ogół dobrze rozpoznanych od strony konserwatorskiej, w większości datowanych i w dużej mierze powiązanych z konkretnymi nazwiskami krakowskich artystów, reprezentujących różny poziom i różne tendencje. Możemy je przy tym zestawić z obrazami malarzy pozakrakowskich (w tym warszawskich). Ta „galeria” dzieł powinna stać się przedmiotem odrębnej analizy, nawet jeśli już teraz wiemy, że będzie to opowieść o powolnym obniżaniu się poziomu malarstwa krakowskiego w XVII w.

Nie sposób jednak zacząć tej analizy bez bliższego zapoznania się z wystrojem dwóch kaplic najbliżej sąsiadujących z prezbiterium kościoła: północnej (fot. 1), Królewskiej (inaczej - wedle obecnego nazewnictwa - kaplicy św. Benedykta, pierwotnie poświęconej śś. Władysławowi i Brunonowi - Bonifacemu) oraz południowej, Delpacowskiej (św. Romualda), usytuowanej naprzeciw. Spróbujmy przyjrzeć się informacjom ściśle historycznym związanymi z tymi kaplicami.

konserwatorskich oraz z maszynopisu Katalogu zabytków sztuki w Polsce (zob. J. Gajewski, P. Pałamarz, J. Petrus, Kościót p.w. Wniebowzięcia..., dz. cyt.). W przypadku sumarycznego przeglądu nie wydaje się celowe zamieszczanie szczegółowych odnośników bibliograficznych, a publikację podstawy źródłowej tych ustaleń odłożyć trzeba do czasu ponownego udostępnienia do badań archiwum bielańskiego. 
Zachowały się rachunki pozwalające ustalić czas, zakres i autorstwo najważniejszych prac prowadzonych w kaplicy Królewskiej. W jednym z poszytów akt bielańskich z Biblioteki Czartoryskich w Krakowie ${ }^{24}$ odnaleźć można spis wypłat dla artystów czynnych w kaplicy, datowany na 1633 r. (którą to datę należy uznać za początkową $\mathrm{w}$ stosunku do prac wymienionych w zestawieniu), ale faktycznie oddający stan z 1637 r. Z innych źródeł wiemy także o kolejnych działaniach przy wystroju kaplicy, ciągnących się do $1642 \mathrm{r}^{25}$, ale prace zrealizowane w pierwszym okresie, niedługo po 1633 r., wydają się najważniejsze z punktu widzenia malarskiego wystroju wnętrza. Dzięki cytowanemu zestawieniu przede wszystkim zyskujemy potwierdzenie, że fundacja ta finansowana była przez króla Władysława IV Wazę. Osobistą inicjatywę monarchy potwierdzają zresztą zachowane elementy wystroju samej kaplicy: kartusz z herbem królewskim wykonany przez sztukatora Philiberta i umieszczony na zewnątrz arkady prowadzącej do kaplicy (fot. 1), herby wazowskie na portalach w ścianach tarczowych (fot. 2), dostarczonych przez Sebastiana Salę w pierwszej fazie prac (portale są wzmiankowane $\mathrm{w}$ podstawowym zestawieniu), wreszcie motywy heraldyczne wplecione w polichromię na ścianach kaplicy. Zapewne wola królewska spowodowała, iż prace przy tej fundacji, przynajmniej początkowo, prowadzono stosunkowo szybko. Wspomniane zestawienie z Biblioteki Czartoryskich oraz nieco późniejsze (datowane na czas od 1637 r.) kontrakty zachowane w archiwum klasztornym mówią o wykonaniu m.in. posadzki, stopni, balustrad i w ogóle partii marmurowych (Sebastian Sala), ołtarza (Georg Zimmermann - realizacja w latach 1635-1636 ${ }^{26}$ ), złoceń stiuków na ścianach (kolejno Jan Chryzostom Proszowski, Stanisław Boja,

24 Biblioteka Książąt Czartoryskich w Krakowie (przy Muzeum Narodowym w Krakowie), rkps sygn. 3214: Akta dotyczące klasztoru kamedułów na Bielanach w Krakowie z lat 1604-1852 (głównie z XVII w.), poz. 13, s. 61 - treść tego wykazu dość wiernie przytoczył J. Ptaśnik (art. cyt.), do którego publikacji odwołujemy się w niniejszym artykule.

25 Chronologiczne zestawienie prac w kaplicy Królewskiej znajduje się w drugiej części cytowanej pracy J. Gajewskiego (pozostającej w maszynopisie - por. wyżej przypis 8), Wystrój..., Część II, podrozdział: Wykaz wszystkich (znanych) prac wykonanych po $1618 \mathrm{r}$. w kościele i klasztorze OO. Kamedułów na Bielanach pod Krakowem, s. 294-296; tu Gajewski słusznie datuje działania wzmiankowane w dokumencie z Biblioteki Czartoryskich na czas przed $1637 \mathrm{r}$. W zestawieniu tym uwzględniono bowiem prace znane też z kontraktów, z których najpóźniejszy podpisany został 3 IX 1637 r. (chodzi o kontrakt z Sebastianem Salą na wykonanie posadzki do kaplicy).

${ }_{26}$ Ostatnio zagadnieniem nieistniejącego dziś jako całość, pierwotnego ołtarza z kaplicy, będącego dziełem warsztatu Georga Zimmermanna, zajął się Michał Wardzyński, Rzeźba nowożytna w kręgu Jasnej Góry i polskiej prowincji zakonu paulinów, 1, Ośrodek rzeźbiarski w Częstochówce pod Jasną Górą 1620-1705, Warszawa 2009, T. 1, s. 59-60, 64, 241, 254, T. 2, il. 466-468 na tabl. 146. 
zwany Wódką, i przede wszystkim Tomasz Dolabella), wreszcie jej wystroju malarskiego - tego, co nam wydaje się tak bardzo ważne, a co dla ludzi XVII wieku stało w dalszej kolejności za złoceniem.

Kwestię chronologii prac malarskich prowadzonych w kaplicy, zamkniętych latami 1633-1636, porządkuje zachowany w archiwum klasztornym, uwzględniony dotąd tylko w niepublikowanej pracy Jacka Gajewskiego, kontrakt na wykonanie dekoracji malarskiej w kaplicy, podpisany przez konwent z krakowskim artystą Janem Chryzostomem Proszowskim w 1634 r. $^{27}$. Wiadomo skądinąd, że Proszowski pracy swojej nie wykonał i popadł w konflikt z konwentem kamedułów, którzy niedługo po podpisaniu umowy zdecydowali się wystąpić przeciw niemu na drogę sądową ${ }^{28}$, a w 1635 r. wzmiankowane są sumy, które Proszowski winien był klasztorowi, niewątpliwie w związku z niedopełnieniem zobowiązań wynikających z umowy o prace malarskie - chodziło kolejno o $500^{29}$ i 178 złotych $^{30}$. Zestawienie wydatków zachowane w Bibliotece Czartoryskich informuje, że ostatecznie dekoracja malarska, a także dokończenie złoceń na sklepieniach („za obrazy y od złocenia ostatka tey kaplicy y malowania”) została zrealizowana przez Tomasza Dolabellę, za co znany malarz otrzymał sporą sumę 1200 złotych $^{31}$. Dotychczas podawana w literaturze

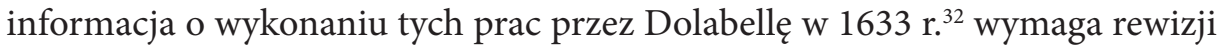
w świetle informacji o istnieniu kontraktu Proszowskiego z 1634 r. Włoski malarz wykonał dekorację malarską zapewne w latach 1635-1636. Zapiska z Biblioteki Czartoryskich brzmi jednoznacznie, ale informacja o autorstwie Dolabelli wymaga oczywiście skonfrontowania ze stylem obrazów zachowanych obecnie w kaplicy Królewskiej.

${ }^{27}$ J. Gajewski, Wystrój..., dz. cyt., cz. II, Aneks 53 na s. 164-165. Pełna analiza tego kontraktu będzie możliwa z chwilą uzyskania dostępu do oryginału dokumentu znajdującego się w archiwum klasztoru bielańskiego.

28 W zestawieniu wydatków odnoszącym się do kaplicy Królewskiej, zachowanym w Bibliotece Czartoryskich uwzględniono najpierw wydatek 200 florenów wypłaconych Proszowskiemu za złocenie sklepienia kaplicy, a potem wydatek 41 florenów i 8 groszy „na prawo z tymże malarzem Proszowskim, który niedosyt czynił obligatiey” (J. Ptaśnik, art. cyt., szp. LXVII).

29 S. Tomkowicz, Przyczynki do historyi kultury Krakowa w pierwszej połowie XVII w., Lwów 1912, s. 163-164 (była to druga rata należna klasztorowi kamedułów Proszowskiego).

${ }^{30}$ J. Pagaczewski, [komunikat w:] „Sprawozdania Komisji do Badania Historii Sztuki w Polsce”, T. 6, 1900, s. XXXII-XXXIII.

31 J. Ptaśnik, art. cyt., szp. LXVII.

32 W taki sposób datowane są obrazy Dolabelli z kaplicy Królewskiej w artykule Żmudzińskiego O potrzebie..., dz. cyt., s. 139 (przygotowując cytowaną rozprawę autor nie miał dostępu do kontraktu klasztoru z Proszowskim z 1634 r.). 
Powstanie kaplicy św. Romualda niemal nie zostawiło śladów w źródłach pisanych. Fundatorem wystroju kaplicy był Rafał del Pace (zmarły w 1654 roku), krakowski ławnik i rajca (kolejno od 1638 i 1639 r.), bogaty kupiec jedwabny, wywodzący się z florenckiej rodziny osiadłej w Krakowie w 1577 roku $^{33}$. Wybór Bielan na miejsce jego najbardziej okazałej fundacji można wytłumaczyć m.in. faktem, iż w 1618 roku jego brat Mikołaj (zmarły przed 1673 r.) został (jako o. Ambroży) kamedułą na Bielanach ${ }^{34}$. Informację o fundacji del Pace zawiera m.in. napis w samej kaplicy, umieszczony w kartuszu na szczycie arkady wejściowej od strony wnętrza, znany już z pomnikowej publikacji Szymona Starowolskiego ${ }^{35}$. Inskrypcja ta jako datę fundacji podaje rok 1643, ale właściwie nie wiemy, w jaki sposób data ta odnosi się do etapów wykonywania dekoracji kaplicy - czy jest to raczej data kończąca, czy rozpoczynająca te prace. O tym, jak słabo rozpoznane są zabytki bielańskie, niech świadczy fakt, że mimo ogólnej dostępności napisu nawet w nowszej literaturze podawana jest informacja o tym, że inskrypcja nie zachowała się $e^{36}$, a jako data fundacji kaplicy podawany jest błędnie $1648 \mathrm{r}^{37}$ (co wynika z bezkrytycznego powtarzania mechanicznego błędu Stanisława Tomkowicza ${ }^{38}$ ). Wystrój kaplicy w tej sytuacji należy hipotetycznie datować na około 1643 r., choć można też przypuszczać, że pewne jego elementy - np. stiuki sklepienia (fot. 12) - powstały wcześniej, równolegle z podobnymi elementami wystroju kaplicy Królewskiej, a więc około 1632-1633 r. W tej sytuacji za fundację Rafała del Pace z około 1643 r. można uznać zespół obrazów na sklepieniu kaplicy i arkady oraz sześć płócien zdobiących ściany. Ten cykl przedstawień uzupełnia obraz w ołtarzu kaplicy, przedstawiający Sen św. Romu-

33 Zob. K. Pieradzka, Del Pace (Delpace, Delpacy, de Pace, della Pace) Rafał († przed r. 1655), kupiec, rajca krakowski, [w:] Polski Słownik Biograficzny, t. 5, Kraków 1939-1946, s. 60-61. Datę śmierci Del Pacego skorygował Z. Noga, Urzędnicy miejscy Krakowa. Część 2: 1500-1794, [w:] Spisy Urzędników Miejskich z Obszaru Dawnej Rzeczypospolitej, Śląska i Pomorza Zachodniego, t. 3: Małopolska, z. 1: Kraków, Kraków 2008, s. 286; tamże na s. 81 i 217 informacje o datach objęcia przez niego urzędów miejskich.

34 M. Rożek, Mecenat artystyczny mieszczaństwa krakowskiego w XVII wieku, [w:] Biblioteka Krakowska, nr 118, Kraków 1977, s. 149.

35 S. Starowolski, Monumenta Sarmatorum, Kraków 1655, s. 213 - treść napisu zacytowana przez Starowolskiego zgadza się w całej rozciągłości z inskrypcją zachowaną ponad wejściem do kaplicy od wewnątrz (w latach 90. XX w. inskrypcja została uczytelniona w czasie prowadzonych tamże prac konserwatorskich).

36 M. Rożek, Mecenat..., dz. cyt., s. 147.

37 K. Pieradzka, Del Pace..., dz. cyt., s. 60.

38 S. Tomkowicz, Powiat krakowski. Inwentaryzacya zabytków Galicyi zachodniej III, „Teka Grona Konserwatorów Galicyi Zachodniej”, t. 2, 1906, s. 21. 
alda, przeniesiony do obecnego późnobarokowego retabulum z pierwotnego ołtarza z XVII w. i przy tej okazji częściowo zasłonięty. Związek tego obrazu, zależnego od kompozycji włoskiego malarza Andrea Sacchi, z pozostałym wystrojem malarskim kaplicy Delpacowskiej z czasów jej fundacji powinien być poddany odrębnej analizie ${ }^{39}$.

Program ikonograficzny dzieł malarstwa z XVII w. w obu kaplicach wymaga komentarza. O ile w kaplicy Delpacowskiej sprawa przedstawia się prosto, gdyż w całości jest ona poświęcona św. Romualdowi, założycielowi zakonu kamedułów, o tyle sprawa przedstawień w kaplicy Królewskiej nie jest już tak oczywista. O całości programu kaplicy mówić jest dziś trudno, gdyż nie zachował się pierwotny ołtarz, zastąpiony około 1738 roku przez retabulum autorstwa Antoniego Frączkiewicza, nie przetrwał też pierwotny obraz z tego ołtarza. O ołtarzu z czasów fundacji wazowskiej wiemy tyle, ile mówią: umowa z jego wykonawcą Georgiem Zimmermannem oraz zachowane relikty, przede wszystkim kartusz z Orłem Białym i herbem Wazów (w Muzeum Narodowym w Krakowie) i figury św. Zygmunta i Władysława w zbiorach Zamku Królewskiego na Wawelu ${ }^{40}$. Razem $\mathrm{z}$ herbem ponad wejściem do kaplicy oraz $\mathrm{z}$ herbami na portalach i malowidłach ściennych składają się one na program dynastyczny, akcentujący też osoby patronów dwóch polskich monarchów z dynastii Wazów: fundatora kaplicy Władysława IV - św. Władysława i jego ojca Zygmunta III - św. Zygmunta. Oczywisty w tym kontekście wydaje się cykl obrazów z życia św. Władysława, obejmujący malowidła na sklepieniu (fot. 5-6) obrazujące apoteozę świętego i jego cuda (wykonane na tynku techniką tłustej tempery), a także pięć obrazów sztalugowych (fot. 7-10): cztery w ościeżach arkady (epizody z życia świętego) i jeden na ścianie wschodniej (Kanonizacja). Cykl ten wykonany został przez Dolabellę - jak już powiedziano - dopiero w latach 1635-1636, jednak nieco podobny cykl przewidziany był umową spisaną z Proszowskim w 1634 r. Przy czym w pierwotnym zamyśle wątek fundatorski w dekoracji malarskiej kapli-

${ }^{39}$ O obrazie pisał M. Skrudlik (Tomasz Dolabella..., dz. cyt., s. 141), wskazując na zależność od dzieła Sacchi; Jacek Gajewski (Prace Jana Eliasza Hoffmanna..., dz. cyt., przypis 21 na s. 263) odnalazł inne włoskie źródła tej kompozycji, a dzieło datował hipotetycznie na czas około 1648 r. i przypisał krakowskiemu malarzowi Janowi Koyowi, twórcy źródłowo potwierdzonych obrazów w bielańskim kapitularzu.

$40 \mathrm{Na}$ temat pierwotnego ołtarza zob. J. Gajewski, Prace Antoniego Frączkiewicza..., s. 363 i 365, oraz przypis 5 na s. 363. Ostatnio Wardzyński, Rzeźba nowożytna w kręgu Jasnej Góry..., dz. cyt. (por. wyżej przypis 26), omówił zidentyfikowane wcześniej relikty ołtarza z XVII w. i jako pierwszy związał z nim dwie figury aniołów umieszczone wtórnie w zwieńczeniu obecnego retabulum z 1638 r. (tamże, s. 254). 
cy był jeszcze dobitniej zaakcentowany: Proszowski miał na ścianach bocznych wymalować przedstawienia triumfów wojennych Władysława IV - związanych z wojną o Smoleńsk w latach 1632-1634 i planowaną w 1634 r. wyprawą przeciw Turcji (do wojny tej ostatecznie nie doszło) ${ }^{41}$. Z przedstawień tych zrezygnowano w chwili powierzenia dekoracji malarskiej Dolabelli. Tym samym program „królewski” wystroju kaplicy uległ pewnemu osłabieniu.

Symptomatyczna jest w związku z tym obecność drugiego wątku programu dekoracji malarskiej kaplicy, obejmującego sceny z życia św. Brunona (zwanego także inaczej św. Bonifacym). Pięć z sześciu scen tworzących cały cykl (fot. 11) rozmieszczono na wąskiej drewnianej boazerii biegnącej przy posadzce wzdłuż ścian bocznych kaplicy; obrazują one misję św. Bonifacego na Rusi (szóste przedstawienie to Stygmatyzacja św. Franciszka, mało zrozumiała w tym kontekście). Cechy stylowe tych obrazów wskazują, że umieszczono je w kaplicy później, nie w czasach fundacji ${ }^{42}$, ale wątek odnoszący się do osoby św. Brunona był już obecny w kaplicy w najstarszym okresie tworzenia jej wystroju, o czym świadczy jeden $\mathrm{z}$ dwóch wielkich obrazów na ścianach bocznych kaplicy (od strony zachodniej). Jego ikonografia wymaga jednak szerszego objaśnienia.

Brunon z Kwerfurtu, urodzony około 974 roku, kanonik magdeburski, należał do otoczenia cesarza Ottona III. Razem z nim przebywał we Włoszech, gdzie pozostał jako mnich, początkowo na Awentynie w Rzymie, a później w eremie św. Romualda w Pereum koło Rawenny. Brunon miał początkowo należeć do grupy eremitów, którzy udali się do Polski i tu ponieśli męczeńską śmierć. W późniejszym okresie, otrzymawszy od papieża sakrę arcybiskupią, odbywał wyprawy na Węgry (i stamtąd na Ruś), a potem z obszaru Polski, za wiedzą i przychylnością Bolesława Chrobrego, regularnie wysyłał misje do pogan i sam brał w nich udział. Zginął śmiercią męczeńską w 1009 roku z rąk Jaćwięgów na pograniczu rusko-pruskim ${ }^{43}$.

Problem kultu św. Brunona w Polsce w czasach nowożytnych wymagałby osobnego naświetlenia. Niewątpliwie przywołanie jego osoby jako apostoła Rusi musiało być aktualne w latach 30 . XVII w., w czasach gdy w polityce Rzeczypospolitej tak ważny był problem relacji z Moskwą, unii z Kościołem wschodnim oraz praw dyzunitów. Wymaga osobnego naświetlenia kwestia, z czyjej właściwie inicjatywy w dekoracji kaplicy Królewskiej zaakcentowa-

${ }^{41}$ Zob. J. Gajewski, Wystrój..., Aneks 53 na s. 164-165. Zob. też uwaga w przypisie 27.

$42 \mathrm{Na}$ temat datowania tych obrazów zob. wyżej przypis 21.

43 Podstawowe informacje na temat św. Brunona zob. H. Fros SJ, F. Sowa, Księga imion i świętych, t. 1: A-C, Kraków 1997, szp. 509-511. 
no wątek misyjnej działalności św. Brunona. W pierwotnym programie kaplicy szczególnie eksponowano osobę króla Władysława IV i jego zwycięstw. Król w latach 30. XVII w., począwszy od sejmu koronacyjnego w Krakowie w 1633 r., wbrew swoim doradcom, wbrew oporowi części katolickiej hierarchii oraz duchownych unickich próbował doprowadzić do swoistego pokoju religijnego w Polsce. Chciał zakończyć spory między unitami i dyzunitami, zapewnić ludności prawosławnej pełnię praw na terenach, gdzie obrządek ten przeważał: prawo do budowy cerkwi, zakładania szpitali i szkół, prowadzenia drukarni i wydawania ksiąg, dostęp do urzędów miejskich. Władysław IV był krytycznie nastawiony wobec skrajnych poglądów dysydentów (nie akceptował Braci Polskich), był też przeciwny rozszerzaniu przywilejów dla Żydów. Jego tolerancyjna postawa wynikała więc raczej z zamysłów politycznych ${ }^{44}$. Nie można wykluczyć, że akcentowanie w dekoracji kaplicy ufundowanej przez króla na Bielanach historycznych praw Kościoła katolickiego do misyjnej działalności na Rusi miało charakter delikatnej polemiki z głównym fundatorem, prowadzonej w czasie, gdy monarcha nie miał już chyba bezpośredniego wpływu na tworzenie programu ikonograficznego kaplicy ${ }^{45}$. Zakony w Polsce były generalnie przeciwne ustępstwom króla wobec prawosławnych mieszkańców Rzeczypospolitej ${ }^{46}$. Kameduli, o których zaangażowaniu się w aktualne spory religijno-polityczne w Polsce w 2. ćwierci XVII w. dotąd szerzej nie pisano, na pewno interesowali się problemami unii, co starał się rozbudzić w zakonnikach ich fundator Mikołaj Wolski, ofiarowując niedługo przed 1630 r. do konwentu bielańskiego specjalnie sprowadzoną z Rzymu podobiznę unickiego męczennika św. Jozafata Kuncewicza ${ }^{47}$. Możliwe, że ta część wystroju malarskiego kaplicy Królewskiej, która odnosi się do św. Bru-

${ }^{44}$ Uwagi ogólne na temat stosunku króla Władysława IV do innowierców, w tym szczególnie do dyzunitów, zob. H. Wisner, Władysław IV Waza, Wrocław 1995, s. 131-146 (rozdział: Katolicy, ludzie religii greckiej oraz inni); kontekst europejski tego problemu omawia J. Ambroise, Od Lutra do Mohyly. Polska wobec kryzysu chrześcijaństwa 1517-1648, Warszawa 1994, s. 279 i n. Z bardziej szczegółowych opracowań zob. przede wszystkim: J. Dzięgielewski, O tolerancję dla zdominowanych. Polityka wyznaniowa Rzeczypospolitej w latach panowania Władysława IV, Warszawa 1986.

${ }_{45} \mathrm{Na}$ obecność $\mathrm{w}$ programie kaplicy wątku odnoszącego się do aktualnych problemów roli Kościoła wschodniego w Rzeczypospolitej (jednak bez wchodzenia w kwestie szczegółowe) zwrócił uwagę J. Gajewski, Prace Antoniego Fraczkiewicza..., dz. cyt., s. 365, 368.

${ }^{46}$ H. Wisner, Władysław IV Waza, dz. cyt., s. 132.

${ }^{47}$ M. Łepkowski, Najwcześniejsze przedstawienia św. Jozafata Kuncewicza a problem vera effigies w kształtowaniu się ikonografii świętych w okresie potrydenckim, [w:] Fides. Ars. Scientia. Studia dedykowane pamięci Księdza Kanonika Augustyna Mednisa, red. A. Betlej, J. Skrabski, Tarnów 
nona z Kwerfurtu, stanowi element aktualnej polemiki, w którą włączyli się sami kameduli.

W tej sytuacji intrygująco przedstawia się problem ostatecznego określenia tematu i czasu powstania jednego z dwóch wielkich obrazów umieszczonych na ścianach kaplicy Królewskiej, kompozycji zawieszonej od strony zachodniej (fot. 3-4). Dotychczas temat tej kompozycji określany był ogólnikowo jako Wizyta u pustelnika. Wydaje się, że obraz ten przedstawia epizod z życia św. Romualda, nawiązujący jednak wyraźnie do osoby św. Brunona: Wizytę cesarza Ottona III uśw. Romualda w pustelni w Pereum. W otoczeniu cesarza znajdował się w tym czasie Bruno z Kwerfurtu, a w trakcie prowadzonych rozmów podjęto m.in. decyzję o wysłaniu uczniów św. Romualda do Polski ${ }^{48}$. Obraz ten zapoczątkowuje więc drugi - obok monarszego - podstawowy wątek treściowy dekoracji malarskiej kaplicy Królewskiej.

Czy dekoracja malarska kaplicy usytuowanej przy kościele zakonu o surowej regule, poniekąd odciętego od świata, mogła budzić szersze zainteresowanie w Rzeczypospolitej? Popełnilibyśmy poważny błąd sądząc, iż wystrój i wyposażenie tej świątyni nie mogły w XVII w. znaleźć swojego miejsca w świadomości elit politycznych państwa. Było przeciwnie: to, co działo się w kościele bielańskim, było bacznie obserwowane. Świadczą o tym relacje mówiące o odwiedzaniu kościoła i obserwowaniu wzorcowych rozwiązań w dziedzinie sztuki, jakie tam były stosowane. Przytoczmy tu charakterystyczną wypowiedź. Chyba nie przypadkiem, dokładnie w chwili inauguracji prac w kaplicy Królewskiej, w czasie sejmu koronacyjnego, 13 marca 1633 r., odwiedził Bielany kanclerz Albrecht Radziwił: „będąc swobodniejszym, dosiadłem konia z kilkoma urzędnikami W. Ks. Litewskiego i udałem się na Srebrną Górę kamedułów, odległą o milę od Krakowa. Klasztor ten ogromnym kosztem zbudował marszałek koronny Wolski, jak to oznajmił miejscowy zakonnik, który poręczył mi, że wydano na budowę 500.000 zł. Gmach godny króla, nie szlachcica! Niech Bóg będzie mu wieczną nagrodą. O budowie nie wspominam, skoro może być przez wszystkich w Królestwie oglądana, to tylko dodam, że rzecz jest godna zobaczenia i może się równać z zagranicznymi budowlami” "49. Radziwiłł nie był jedynym, który przyglądał się klasztorowi bielańskiemu w XVII w. Inny kanclerz królestwa, Stefan Kory-

2008, s. 313; obraz ten został ostatnio zidentyfikowany wśród dzieł malarstwa przechowywanych w klasztorze bielańskim i będzie przedmiotem osobnego opracowania.

48 H. Fros SJ, F. Sowa, Księga imion..., dz. cyt., t. 5: R-U, Kraków 2004, szp. 108-109.

49 A. S. Radziwiłł, Pamiętnik o dziejach w Polsce, T. 1: 1632-1636, przełożyli i opr. A. Przyboś i R. Żelewski, Warszawa 1980, s. 294. 
ciński, dysponując w 1657 r. w testamencie przebudowę krakowskiego kościoła św. Szczepana, wyraźnie odwołał się do konkretnego rozwiązania, które znał z kościoła kamedułów ${ }^{50}$. Z kolei litewski szlachcic Stanisław Samuel Szemiot, odwiedzając Bielany w 1680 r., obok innych szczegółów odnotował wygląd nowo wzniesionego wielkiego ołtarza, który został „bardzo dobrą i osobliwą snycerską robotą wystawiony, ale jeszcze nie złocony i podobno złocić nie będą ex ea ratione, aby pozłota subtelnej roboty snycerskiej nie pokryła”. Szemiot odnotował też, iż „kaplice poboczne specjalną robotę sztukatorską mają i ołtarze piękne”51. Tak więc wystrój i wyposażenie bielańskiej świątyni były bacznie obserwowane przez współczesnych, a oryginalny program ikonograficzny znajdujących się tu dzieł malarstwa (np. w kaplicy Królewskiej), zapewne dodatkowo objaśniony przez zakonników, nie mógł pozostać niezauważony.

Odrębne i obszerne zagadnienie, którego nie sposób tu szczegółowo omawiać, to kwestia autorstwa obrazów w kaplicach. I to nie tylko autorstwa rozumianego jako atrybucja konkretnemu artyście znanemu z imienia czy nazwiska. Ważne jest bowiem już samo rozgraniczenie dzieł różnych twórców w omawianym tu zespole kilkudziesięciu obrazów zdobiących dwie najważniejsze kaplice: Królewską i Delpacowską. W literaturze powtarza się opinia głosząca, iż wystrój malarski obu kaplic wykonała pracownia weneckiego malarza Tomasza Dolabelli, czynnego w Krakowie od samego końca XVI wieku, zmarłego w 1650 roku. Ma drugorzędne znaczenie to, że niektórzy badacze mówili o autorskim udziale mistrza, inni o jego warsztacie i uczniach działających już być może samodzielnie. Wszyscy jednak podkreślali, że późne dzieła enigmatycznie rozumianej „pracowni” czy „szkoły” Dolabelli są świadectwem słabnących sił twórczych malarza (lub jego inspiracji - w przypadku działalności uczniów), oderwania od weneckich korzeni i „sarmatyzacji”, polegającej na przejęciu polskich rekwizytów stroju i dostosowywaniu się do upodobań polskiego odbiorcy ${ }^{52}$. Teza ta odgrywała dotąd zasadnicze znaczenie nie tylko w odniesieniu do zabytków z Bielan, ale też w interpretacji licznych dzieł krakowskiego malarstwa sztalugowego 2. ćwierci XVII w.

50 M. Rożek, Nieistniejący kościót św. Szczepana w Krakowie, „Biuletyn Historii Sztuki”, R. 36, 1974, nr 3, s. 221.

51 T. Piersiak, Pustelnia sarmacka, [w:] Literatura polskiego baroku. W kręgu idei. Referaty $z$ konferencji zorganizowanej przez Katedrę Literatury Staropolskiej Katolickiego Uniwersytetu Lubelskiego w Kazimierzu nad Wisła 18-22 X 1993, red. A. Nowicka-Jeżowa, M. Hanusiewicz, A. Karpiński, Lublin 1995, s. 404.

${ }_{52}$ Zagadnienie to szerzej omówione zostało w artykule: J. Żmudziński, O potrzebie..., dz. cyt., szczególnie s. 138-144. 
Malarski wystrój kaplic bielańskich jak żaden inny nadaje się do analizy mającej na celu rozstrzygnięcie tego kluczowego dla krakowskiego malarstwa problemu. Mamy tu bowiem dzieła związane z Dolabellą na podstawie przekazu źródłowego - obrazy w kaplicy Królewskiej, o bezsprzecznie weneckim charakterze (cykl św. Władysława - fot. 5-10)), ale też znajdujące się tamże dzieła, o zupełnie innym wyrazie stylowym (Wizyta cesarza Ottona III u św. Romualda w pustelni w Pereum - fot. 3-4 - oraz późniejszy cykl scen z życia św. Brunona rozmieszczony na boazerii - fot. 11), wreszcie serię obrazów w kaplicy św. Romualda. Możemy te dzieła poddać obecnie dokładniejszej analizie. Cały wystrój malarski kaplic był bowiem konserwowany (pomijając działania wcześniejsze - z końca XIX i 1. połowy XX w. - myślimy tu przede wszystkim o pracach prowadzonych w latach $1960-1964^{53}$, a być może także i w latach następnych oraz powtórnie w latach $1993-1997^{54}$ ), da się więc bardziej precyzyjnie określić zarówno technologiczne właściwości dzieł, jak i stopień zachowania oryginalnych warstw malarskich. Zbyt drastyczne usunięcie w latach 60. zeszłego stulecia autorskich przemalówek z części obrazów z kaplicy św. Romualda (konkretnie z czterech obrazów sztalugowych zawieszonych w ościeżach arkady wejściowej), samo w sobie będące ewidentnym błędem konserwatorskim, dało okazję do wejrzenia w warsztat artysty (fot. 13-14 $)^{55}$. Wszystko to uprawnia nas do postawienia kilku roboczych wniosków.

53 Odnowiono wtedy obrazy sztalugowe w kaplicy Królewskiej, ale nie zachowała się z tego czasu dokumentacja konserwatorska. Wykonanie tych prac potwierdza m.in. notatka w: Dzieło sztuki w konserwacji. Katalog wystawy, Kraków 1976, s. 136, gdzie mowa o odnowieniu przez Krystynę Prądzyńską w 1964 r., w ramach działań Pracowni Konserwacji Zabytków w Krakowie, obrazu Wizyta u pustelnika. Nieco wcześniej, w latach 1960-1962, odnowiono obrazy sztalugowe w kaplicy św. Romualda i tym razem szczęśliwie zachowała się dokumentacja prac: Dokumentacja konserwatorska obrazów Tomasza Dolabelli [z kaplicy św. Romualda], Bielany, Klasztor OO. Kamedułów, Pracownie Konserwacji Zabytków, Kraków, 1960-1962, mps i fot. w zbiorach Archiwum Wojewódzkiego Urzędu Ochrony Zabytków w Krakowie (zakres prac omawia w skrócie Spis dokumentacji konserwatorskich zabytków ruchomych, cz. I: Dla zabytków znajdujących się poza muzeami, vol. 1: A-N, seria „Biblioteka Muzealnictwa i Ochrony Zabytków. Seria B”, t. 39, Warszawa 1975, poz. 515-520 na s. 205-207).

54 Obrazy sztalugowe w obu kaplicach odnawiała Maria Neczaj-Arendarska, a dokumentacja prac przechowywana jest m.in. w archiwum Wydziału Rewaloryzacji Zabytków Krakowa Małopolskiego Urzędu Wojewódzkiego w Krakowie (dawniej w Zarządzie Rewaloryzacji Zabytków Miasta Krakowa).

55 Zob. Dokumentacja konserwatorska obrazów Tomasza Dolabelli [z kaplicy św. Romualda], dz. cyt., passim oraz publikacja: M. Dayczak-Domanasiewiczowa, Bielany pod Krakowem, obrazy z kaplicy św. Romualda, „Ochrona Zabytków”, R. 16, 1963, z. 3 (62), s. 67-68. il. 10 na s. 68. 
Dziełem Tomasza Dolabelli jest niewątpliwie tylko cykl scen z życia św. Władysława w kaplicy Królewskiej, wyobrażony zarówno na sklepieniu (w części głównej kaplicy - fot. 5-6 - oraz na podniebiu arkady), jak i na obrazach sztalugowych (łącznie pięć obrazów na podobraziu płóciennym - fot. 7-10). Dzieła te noszą wyraźne cechy manierystycznego malarstwa weneckiego i ich styl odpowiada znanej wcześniejszej twórczości artysty; obrazy te nie wykazują znaczącego obniżenia się poziomu wykonawstwa w stosunku do dawniejszych dzieł Dolabelli ${ }^{56}$. Jeden tylko duży sztalugowy obraz z kaplicy Królewskiej (Wizyta cesarza Ottona III u św. Romualda w pustelni $w$ Pereum - fot. 3-4) ma cechy stylowe wyraźnie odmienne i dzieło to można w tej chwili hipotetycznie wiązać $\mathrm{z}$ krakowskim malarzem Janem Chryzostomem Proszowskim (1599 - po 1667), który jako pierwszy, na mocy umowy z 1634 r., przystąił do dekorowania kaplicy. Choć umowa ta nie przewidywała wykonania obrazu o takim temacie, a sam artysta szybko popadł $\mathrm{w}$ konflikt $\mathrm{z}$ konwentem kamedułów, to jednak jego autorstwo w odniesieniu do jedynego obrazu wykonanego, jak się wydaje, przed przejęciem całości prac przez Dolabellę (czyli przed 1635 r.) wydaje się prawdopodobne ${ }^{57}$.

Po Dolabelli, zapewne przed 1643 r., pracę na Bielanach podjęły kolejne warsztaty, z których jeden (?) ozdobił całościowo wnętrze kaplicy św. Romualda $^{58}$. Dotychczas uważano jej malarski wystrój za dzieło artystów przynależnych - ogólnie mówiąc - do „warsztatu” Dolabelli lub jego „szkoły”. Pobieżna analiza tego zespołu obrazów wykazuje pewne różnice między malowidłami na sklepieniu (głównym i arkady wejściowej - fot. 12) i łączącymi się z nimi stylistycznie czterema obrazami sztalugowymi zawieszonymi w ościeżach arkady (z których to czterech kompozycji w latach 1960-1962 niepotrzebnie zdjęto „przemalowania” będące w istocie autorskimi poprawkami kompozycji - fot. 13-15) a dwoma największymi obrazami w kaplicy, umieszczonymi na ścianach zachodniej i wschodniej (Postuchanie u cesarza Ottona III i Przeniesienie zwłok św. Romualda $z$ Valdecastro do Fabiano). Pewne charakterystyczne elementy dzieł z pierwszej grupy - obecność licznych przedstawień ptaków, typ pejzażu - zbliżają te obrazy do znajdującej się w kaplicy Królewskiej Wizyty cesarza Ottona III

56 Por. Żmudziński, O potrzebie..., dz. cyt., s. 138-144.

57 Tamże, s. 139, il. 8 na s. 138.

58 Kwestia ikonografii tych kilkunastu przedstawień jest - podobnie jak w przypadku dekoracji malarskiej kaplicy Królewskiej - odrębnym, obszernym zagadnieniem, którego omówienie przekracza ramy artykułu. Analizę tematów poszczególnych przedstawień, których identyfikacja jest nierzadko dyskusyjna, autor odkłada do czasu zamierzonego przygotowania monografii obu kaplic. 
u św. Romualda w pustelni w Pereum (fot. 3-4). Te same cechy napotkać można w niektórych utworach krakowskiego malarstwa 2. ćwierci XVII w., np. w obrazach: Droga na Golgotę, a przede wszystkim Triumf Śmierci z kościoła w Bodzanowie (obecnie w zbiorach Muzeum Archidiecezjalnego w Krakowie), gdzie zaobserwować możemy także występowanie charakterystycznych autorskich przemalówek warstwy malarskiej ${ }^{59}$. Możliwe jest hipotetyczne przyjęcie, w odniesieniu do wyszczególnionej jako pierwsza grupy obrazów z kaplicy św. Romualda, autorstwa wspomnianego już Jana Chryzostoma Proszowskiego, choć można też wskazać na podobieństwo niektórych obrazów z tej grupy do potwierdzonych obecnością sygnatury, znacznie wcześniejszych dzieł Łukasza Porębskiego z kościoła Bożego Ciała na Kazimierzu, odnoszących się do osoby bł. Stanisława Kazimierczyka, datowanych na 1619 r. (szczególnie interesujące jest w tym kontekście przedstawienie Śmierci bł. Stanisława Kazimierczyka - fot. 16) ${ }^{60}$. Z kolei dwa największe obrazy z kaplicy Delpacowskiej wymagałyby odrębnej analizy uwzględniającej ich bardzo zły stan zachowania i obecność rozległych rekonstrukcji (fot. 17). Rozstrzygnięcie kwestii, czy te dwie monumentalne kompozycje stanowią dzieła tego samego warsztatu, który wykonał obrazy z grupy pierwszej, czy też dekorację kaplicy św. Romualda dokończył inny krakowski artysta pracujący w podobnej konwencji, będzie przedmiotem dalszych rozważań.

Fakt, że w dotychczasowych badaniach, w których unikano szczegółowej analizy poprzestając na ogólnych, powierzchownych podsumowaniach, wszystkie obrazy z obu kaplic przypisywano jednej „szkole” malarskiej, wydaje się zrozumiały. Dzieła te wywodzą się z jednej tradycji, a malarze dekorujący kaplicę św. Romualda pozostawali pod wpływem twórczości Dolabelli. Cechowała ich nabyta od tego mistrza umiejętność aranżowania tłumnych wielofigurowych scen (niewątpliwie wsparta wykorzystaniem wzorów graficznych), pewne związki z twórczością weneckiego artysty wykazuje też charakterystyka postaci (oddanych jakże często w sposób nieporadny) i ich twarzy. Równocześnie brak jest w obrazach z kaplicy św. Romualda weneckiego kolorytu i odrębna jest koncepcja pejzażu.

59 Wawel 1000-2000. Wystawa Jubileuszowa, t. 2: Skarby archidiecezji krakowskiej. Muzeum Archidiecezjalne w Krakowie, maj-wrzesień 2000. Katalog, Kraków 2000, poz. kat. II/31 na s. 73-74 (notę kat. opr. B. Frey-Stecowa i J. Żmudziński); t. 3: Ilustracje, Kraków 2000, il. 457.

60 Zob. F. Stolot, Nie wykorzystane źródło do dziejów sztuki Krakowa w XVII i XVIII wieku. Księga wydatków kościoła Bożego Ciała w Krakowie, „Rocznik Krakowski”, t. 44, 1973, s. 76-77; Katalog zabytków sztuki w Polsce, t. 4, Miasto Kraków, część IV, Kazimierz i Stradom. Kościoły i klasztory, 1, red. I. Rejduch-Samkowa i J. Samek, Warszawa 1987, vol. 1: Tekst, s. 62, vol. 2: Ilustracje, il. 282 i 283; zob. też ostatnio M. Fabiański, Złoty Kraków, Kraków 2010, s. 103. 
Wydaje się, że w dwóch najważniejszych kaplicach kościoła bielańskiego - Królewskiej i Delpacowskiej - możemy oglądać dzieła kilku wiodących krakowskich pracowni malarskich czynnych w latach 30. i 40. XVII w. (a w przypadku obrazów z cyklu odnoszącego się do św. Brunona w kaplicy Królewskiej - także później). Ich rozgraniczenie i zdefiniowanie genezy stylu może bardzo poszerzyć naszą wiedzę na temat malarstwa krakowskiego 1. połowy XVII w. Zaprezentowane tu studium miało za zadanie jedynie ocenić stan wiedzy o wystroju malarskim kościoła Kamedułów i wskazać różne potencjalne kierunki badań, które należałoby koniecznie podjąć. Zarówno bowiem historyczne okoliczności fundacji tych dzieł, jak i bogate programy treściowe, wreszcie skomplikowane zagadnienia stylu - stawiają obrazy z Bielan wśród czołowych dzieł krakowskiego i małopolskiego, a więc także i polskiego malarstwa doby manieryzmu i wczesnego baroku.

\section{Riassunto}

Arredamento pittorico delle cappelle della chiesa dei monaci camaldolesi a Bielany e la sua importanza per l'arte di Cracovia della prima metà del Settecento (cappelle: Królewska e Delpacowska)

Larticolo contiene un'analisi delle investigazioni riguardanti l'arredamento pittorico della chiesa dei monaci camaldolesi a Bielany nei dintorni di Cracovia nei secoli XVII e XVIII. Nell'analisi vennero ordinate le informazioni finora conosciute e furono presi pure in considerazione risultati delle indagini dell'autore riguardanti le due cappelle più importanti della chiesa di Bielany che sono collocate vicino al presbitero: da parte settentrionale - la Cappella di San Benedetto (dedicata prima ai Santi Ladislao e Bonifacio) chiamata anche la Cappella Regia (perchè la fondò il re polacco Ladislo IV Vasa), e da parte meridionale - la Cappella di San Romualdo fondata prima del 1643 da un mercante italiano Rafaello del Pace.

All'inizio l'articolo ricorda alcune informazioni sulla chiesa di Bielany che venne costruita negli anni 1609 - 1630 a spese di Mikołaj Wolski secondo un progetto fatto in Italia. Nel secondo periodo dei lavori (dopo 1617) la costruzione si svolse sotto cura dell'architetto lombardo Andrea Spezza. In seguito viene analizzato lo stato dell'indagine 
delle opere della pittura murale dell'arredamento della chiesa che sono relativamente ben conservate, si trovano in maggior parte nei loro posti e parzialmente sono pure conosciuti i nomi dei loro autori. Vanno ricordati prima di tutto i nomi dei due artisti: Venanzio di Subiaco (1579 c - 1659) e Tommaso Dolabella (1570 c - 1650). A Dolabelli e ai suoi discepoli è attribuita la buona parte del'arredamento della chiesa di Bielany che proviene dalla prima metà del Settecento.

L'autore del articolo sostiene però che solo una parte dell'arredamento della Cappella Regia sia l'opera di Tommaso Dolabella, cioè quella proveniente dagli anni 1635-1636 (il ciclo che rappresenta san Ladislao). Le altre immagini di questa cappella e della cappella di San Romulado sono probabilmente un'opera di tre o anche quattro altri studi pittorici di Cracovia della prima metà del Settecento. Gli artisti di quegli studi rimanevano sotto influsso del Dolabella, però erano anche parzialmente indipendenti.

Con questa tesi l'autore conclude il suo articolo, però sicuramente vanno condotte ulteriori ricerche. 


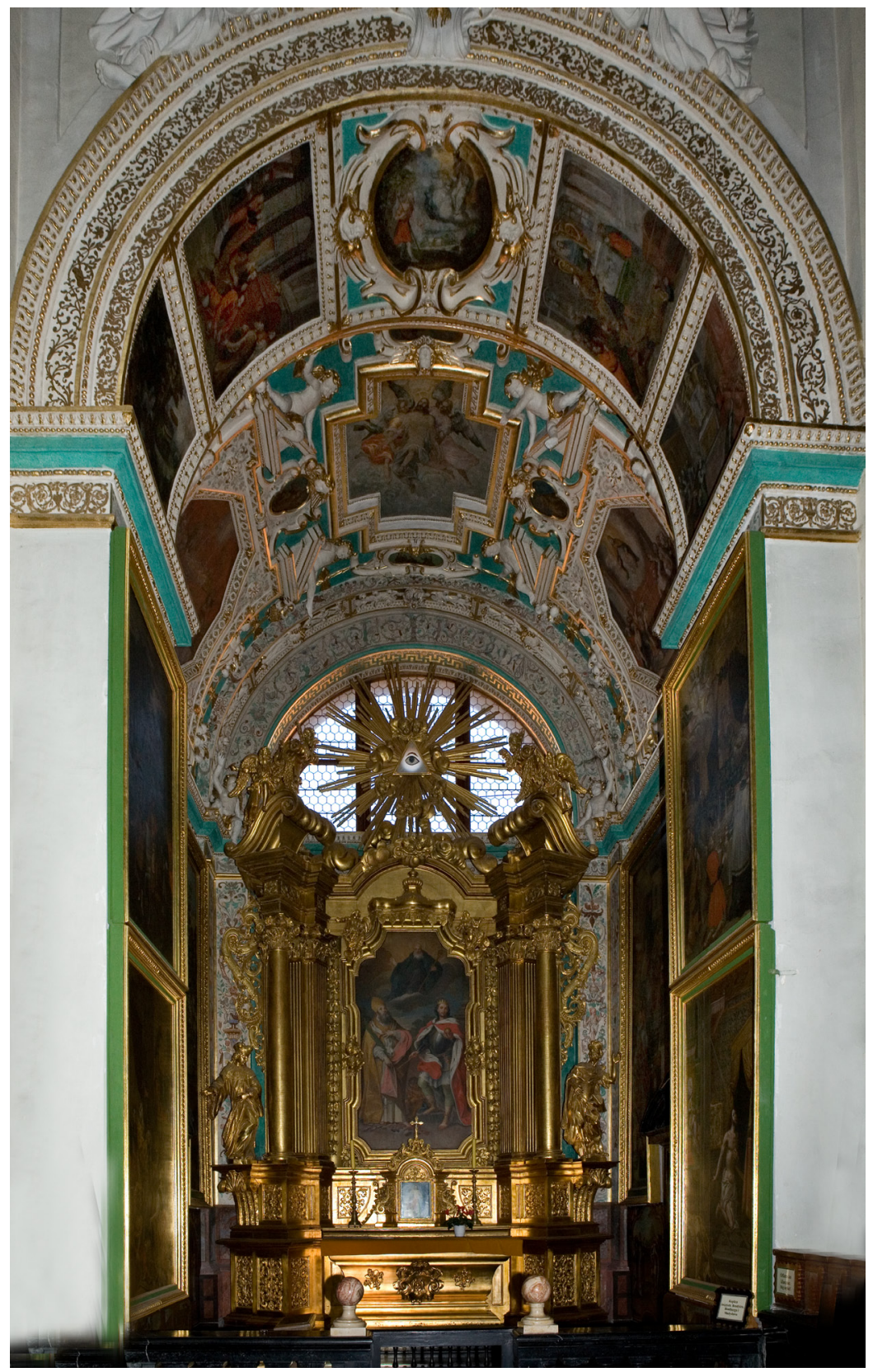

1. Kościół pw. Wniebowzięcia Najśw. Panny Marii, klasztorny kamedułów na Bielanach w Krakowie. Kaplica tzw. Królewska fundacji Władysława IV Wazy - widok od strony nawy głównej. 1633-1642. Fot. J. Kozina. 


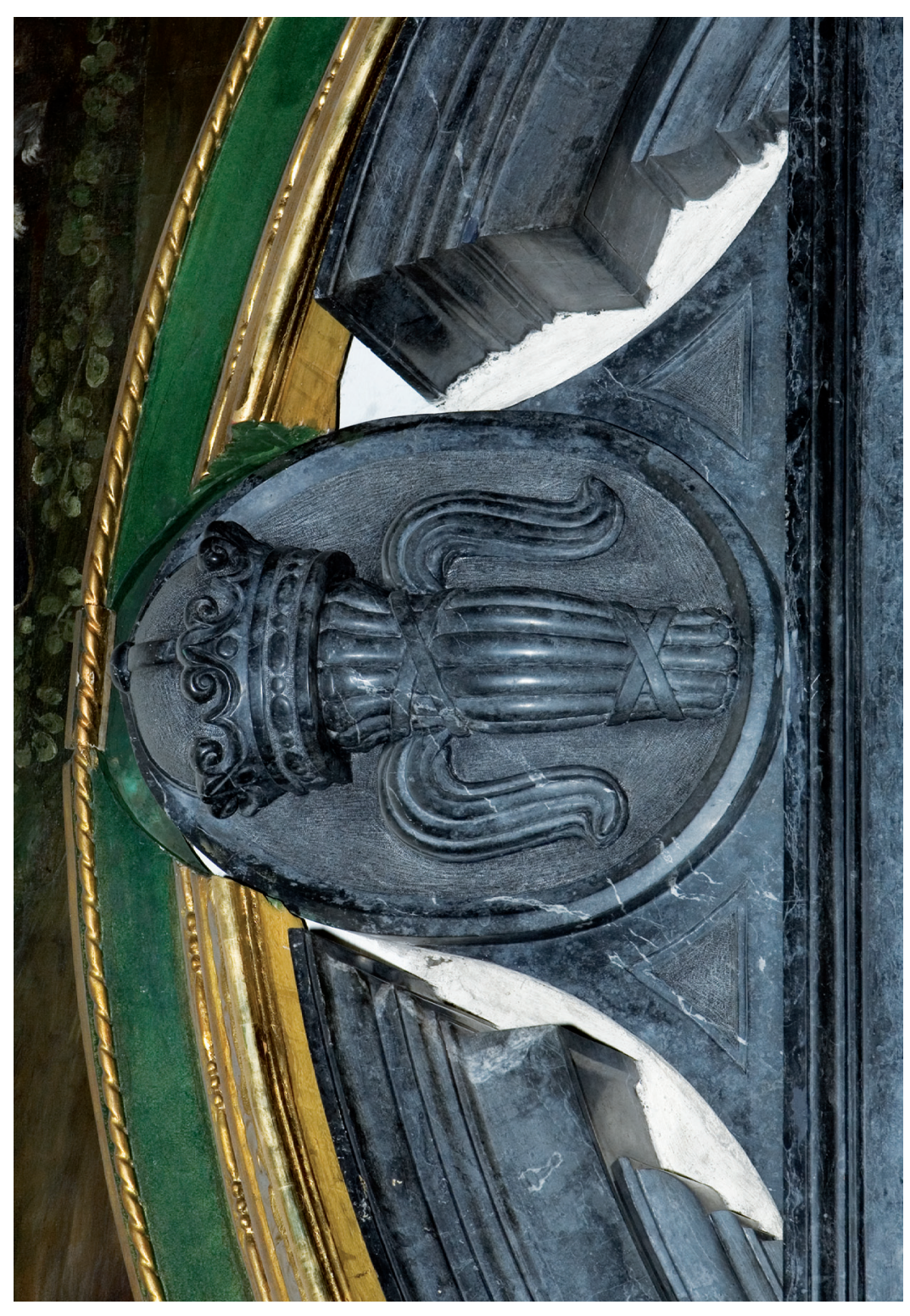

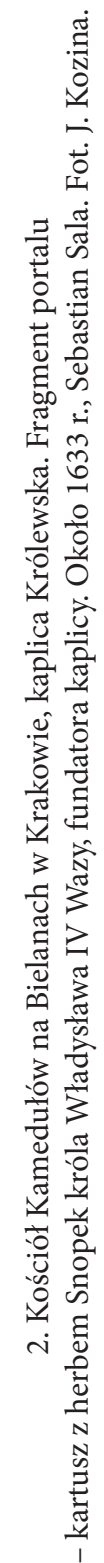




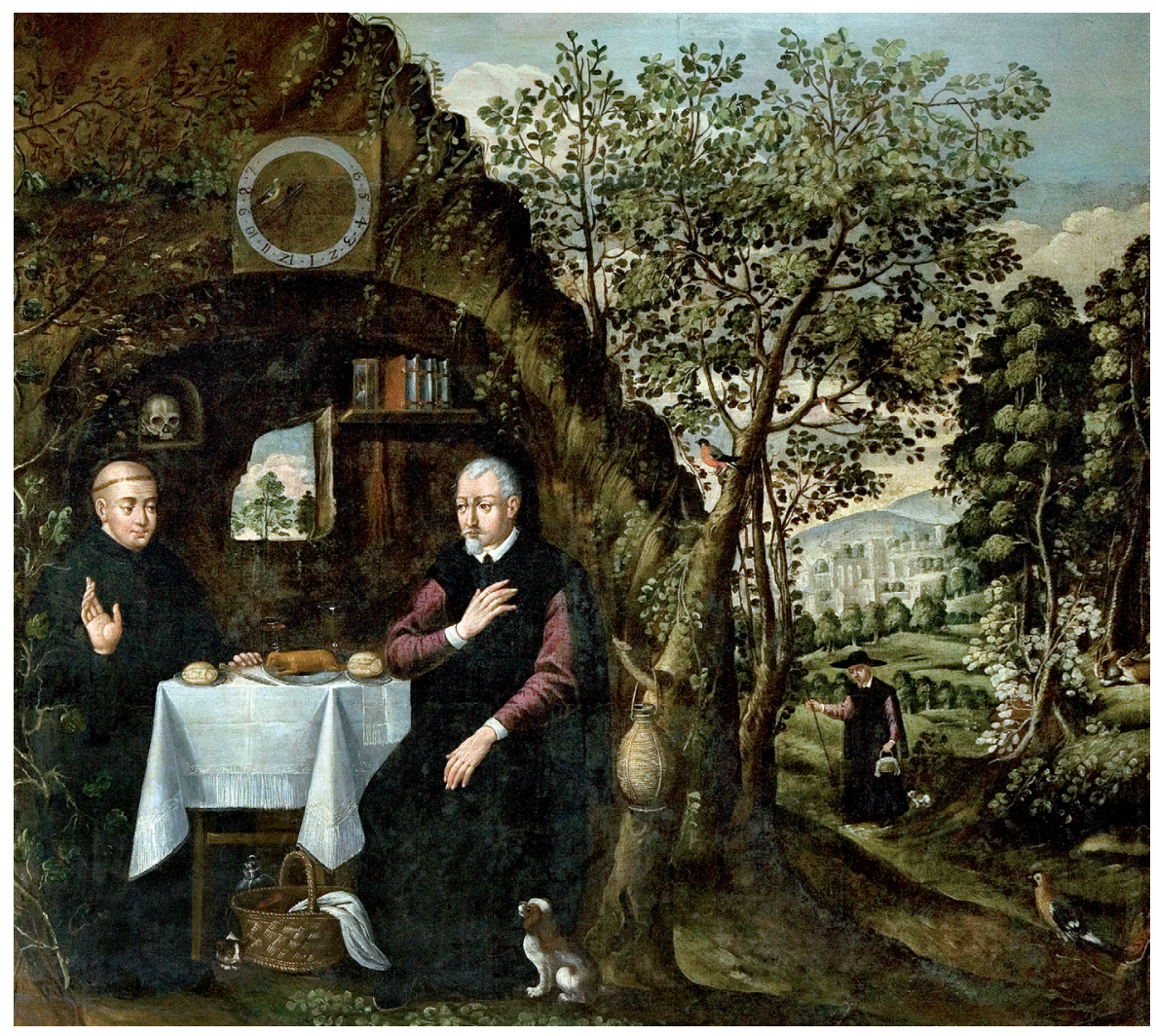

3. Kościół Kamedułów na Bielanach w Krakowie, kaplica Królewska.

Wizyta cesarza Ottona III u św. Romualda w pustelni w Pereum

- obraz na ścianie zachodniej kaplicy. Około 1634-1635, Jan Chryzostom Proszowski (?). Fot. J. Kozina. 


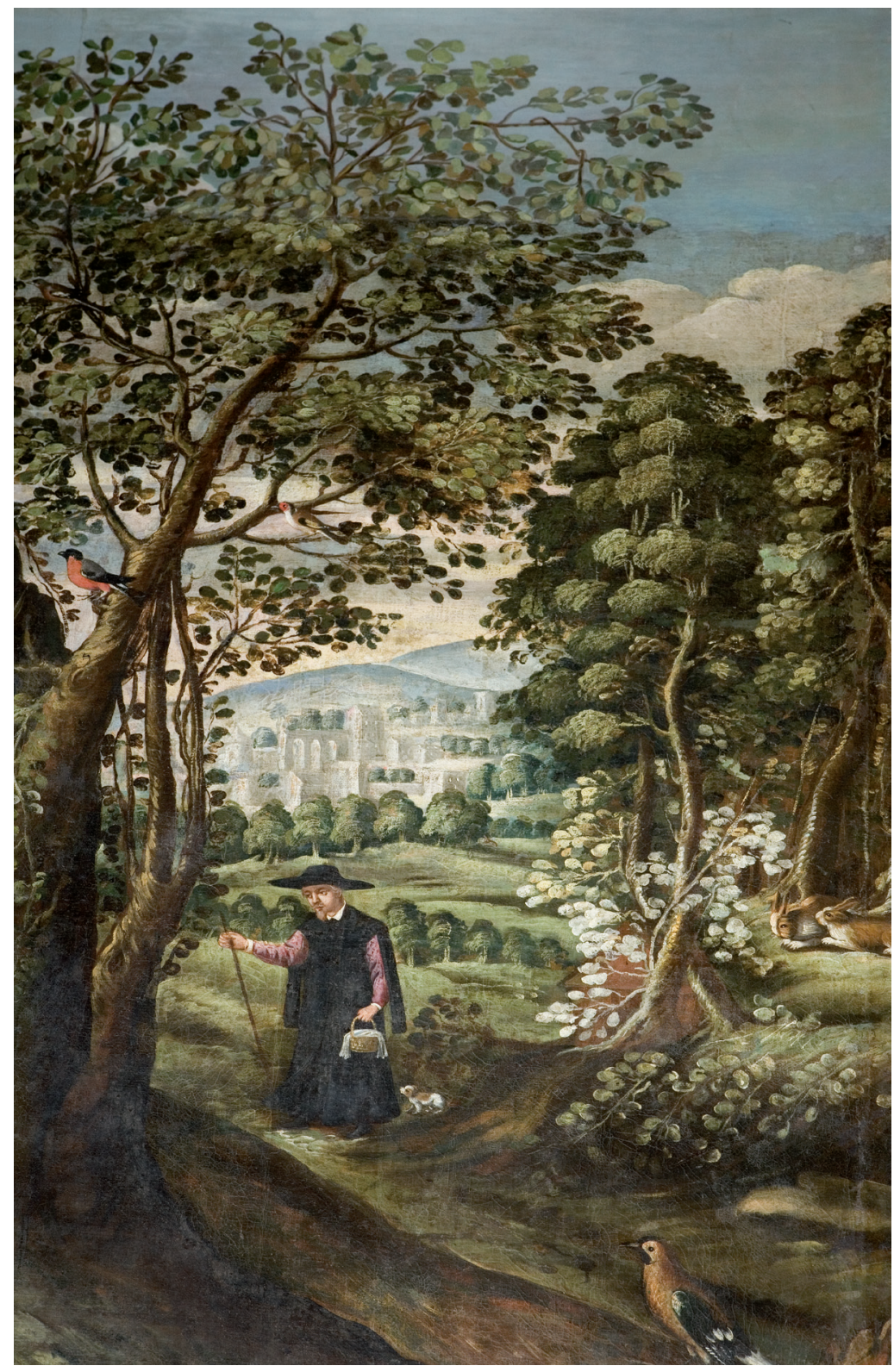

4. Kościół Kamedułów na Bielanach w Krakowie, kaplica Królewska. Fragment obrazu Wizyta cesarza Ottona III u św. Romualda pustelni w Pereum. Około 1634-1635, Jan Chryzostom Proszowski (?). Fot. J. Kozina. 


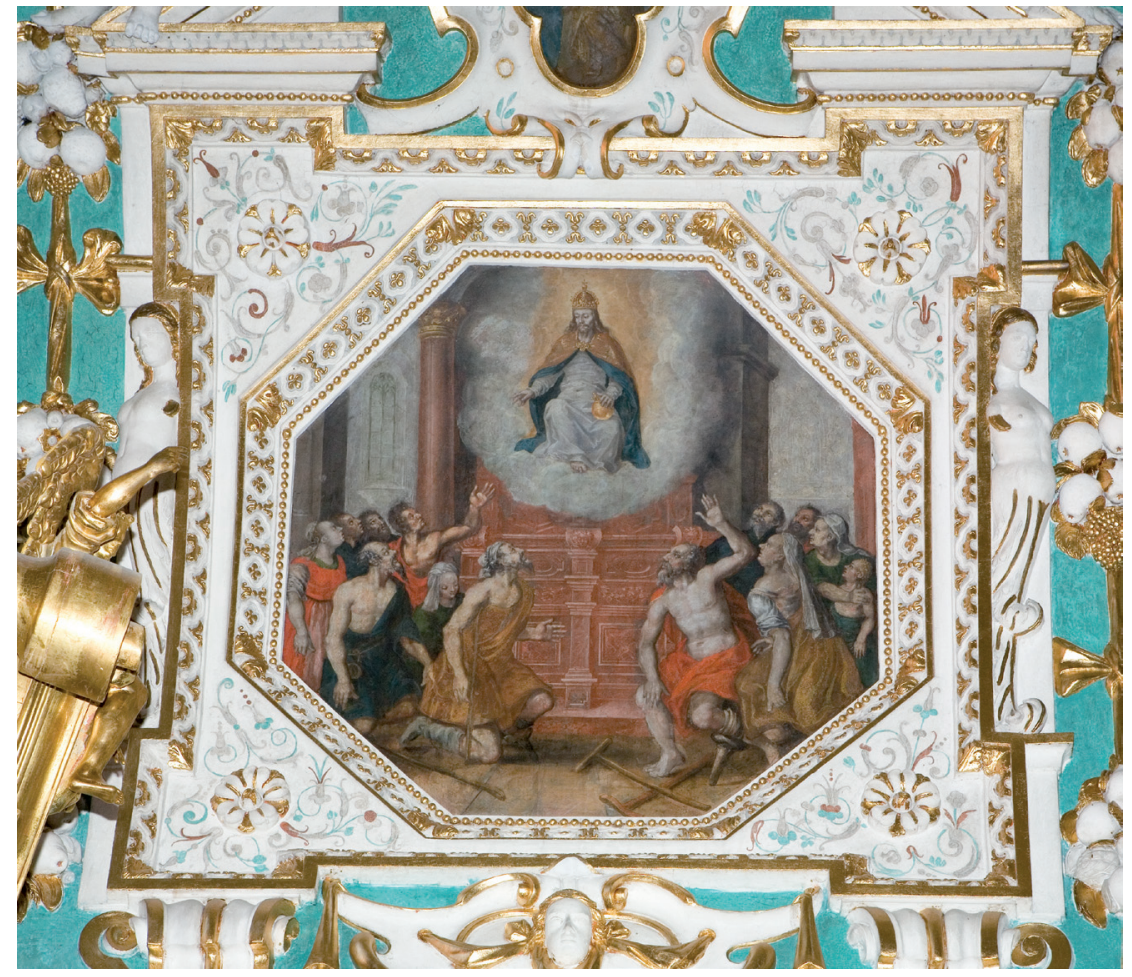

5. Kościół Kamedułów na Bielanach w Krakowie, kaplica Królewska.

Pielgrzymi i kaleki przy grobie św. Władysława

- malowidło na sklepieniu części głównej kaplicy od strony wschodniej. Około 1635-1636, Tomasz Dolabella. Fot. J. Kozina. 


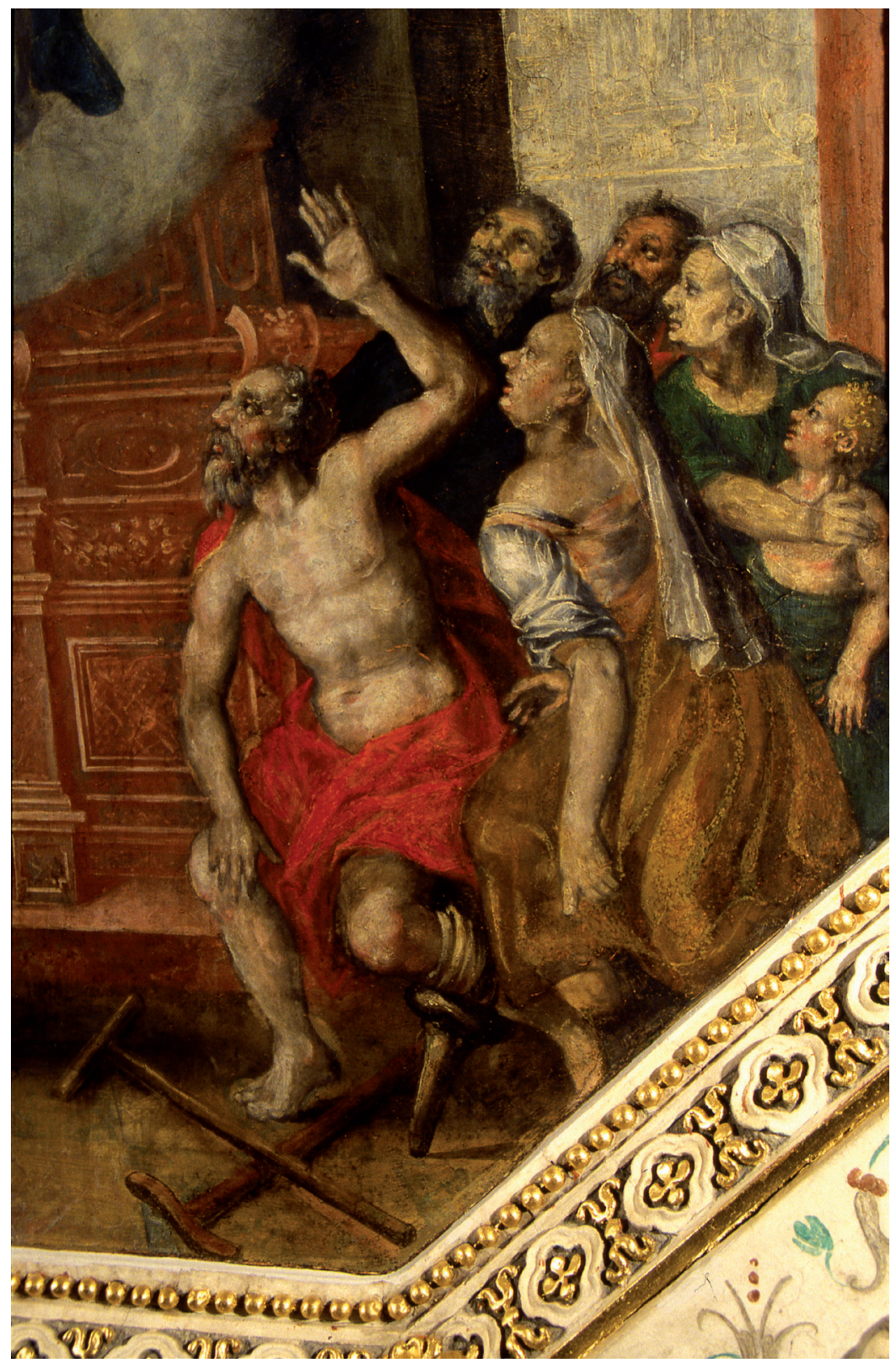

6. Kościół Kamedułów na Bielanach w Krakowie, kaplica Królewska. Fragment malowidła Pielgrzymi i kaleki przy grobie św. Władysława.

Około 1635-1636, Tomasz Dolabella. Fot. J. Kozina. 


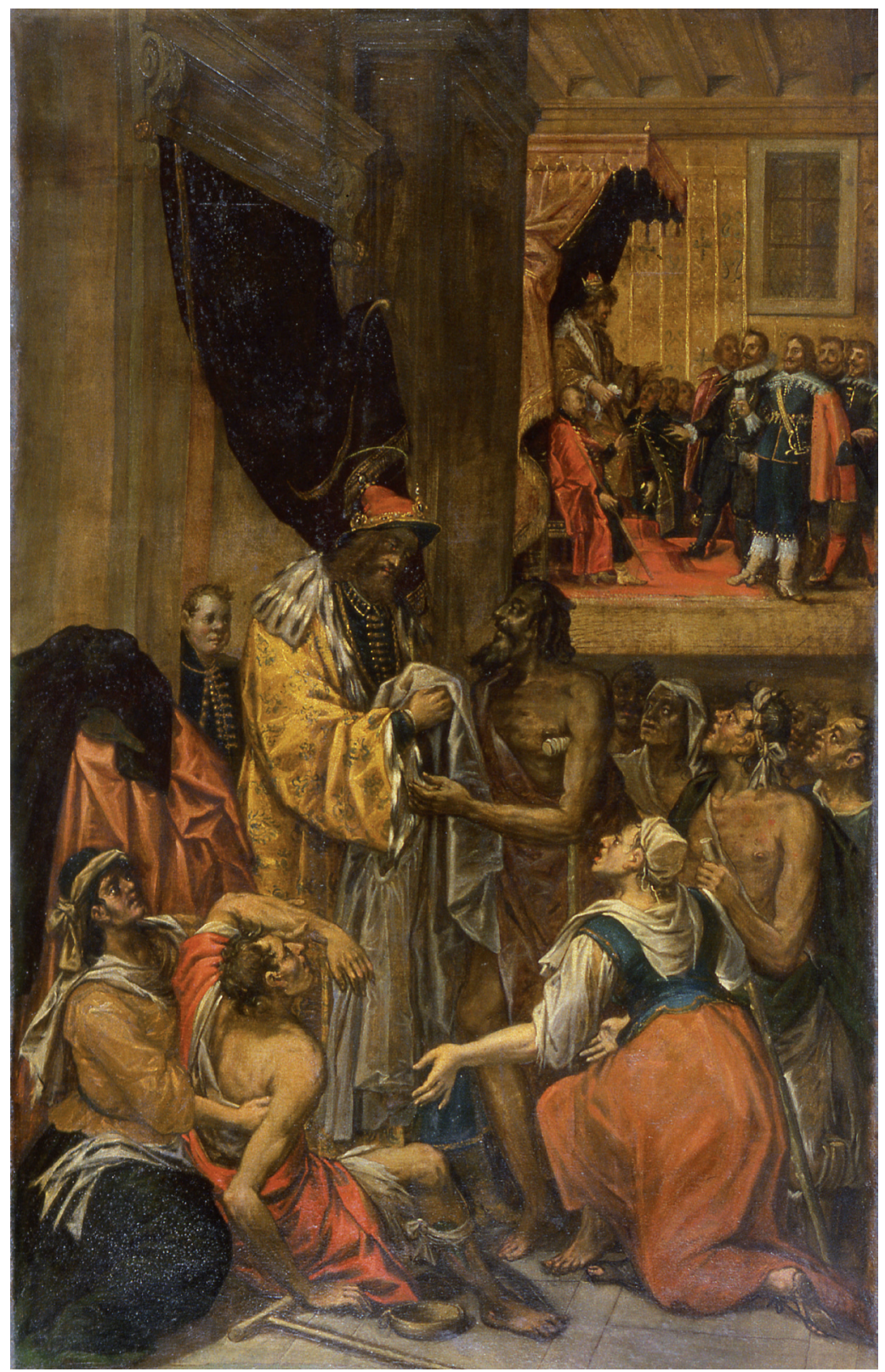

7. Kościół Kamedułów na Bielanach w Krakowie, kaplica Królewska. Św. Władysław rozdajacy jałmużne

- obraz zawieszony w ościeżach arkady wejściowej prowadzącej do kaplicy. Około 1635-1636, Tomasz Dolabella. Fot. J. Walczewski. 


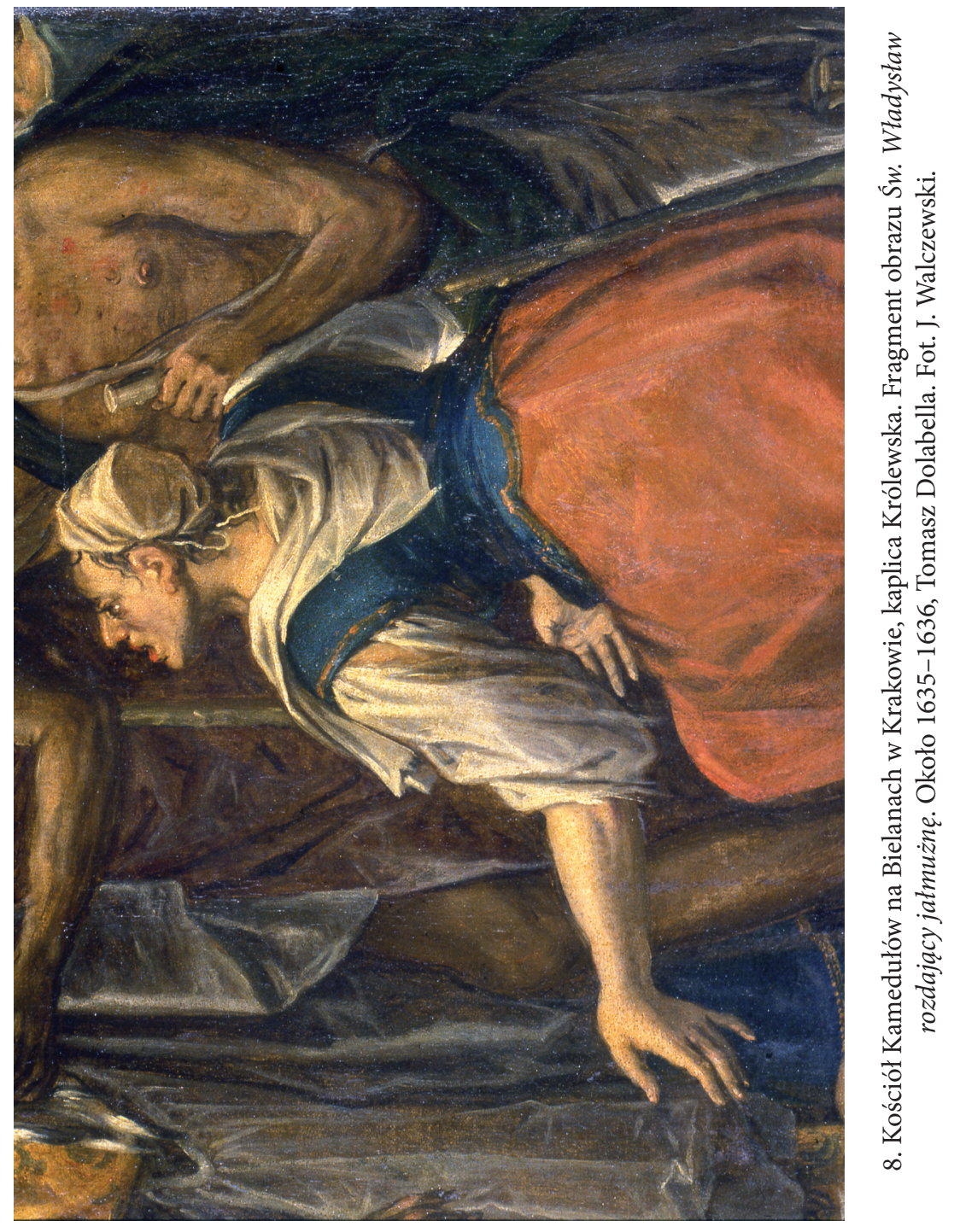




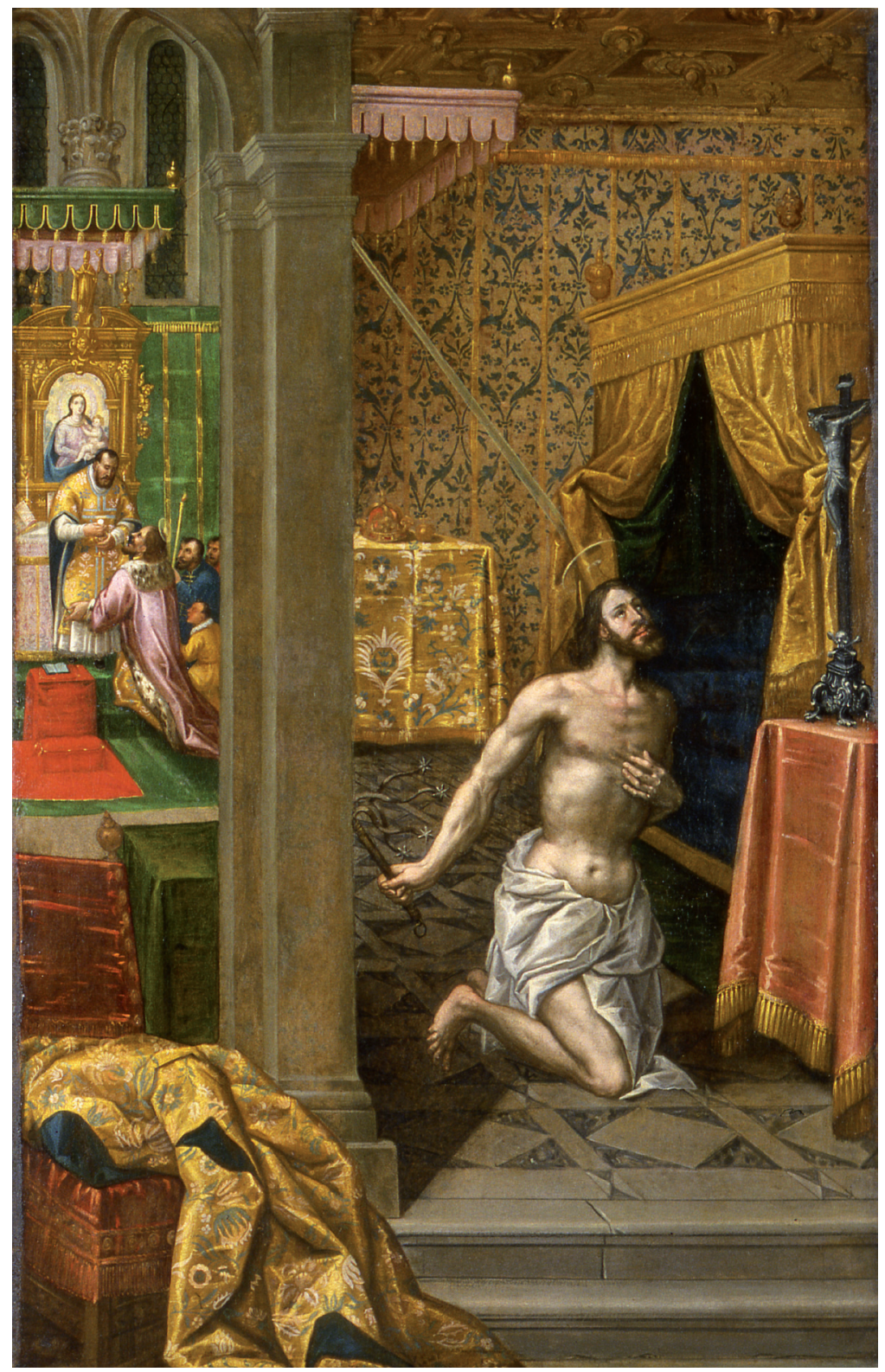

9. Kościół Kamedułów na Bielanach w Krakowie, kaplica Królewska.

Św. Władysław biczujacy się

- obraz zawieszony w ościeżach arkady wejściowej prowadzącej do kaplicy. Około 1635-1636, Tomasz Dolabella. Fot. J. Walczewski. 


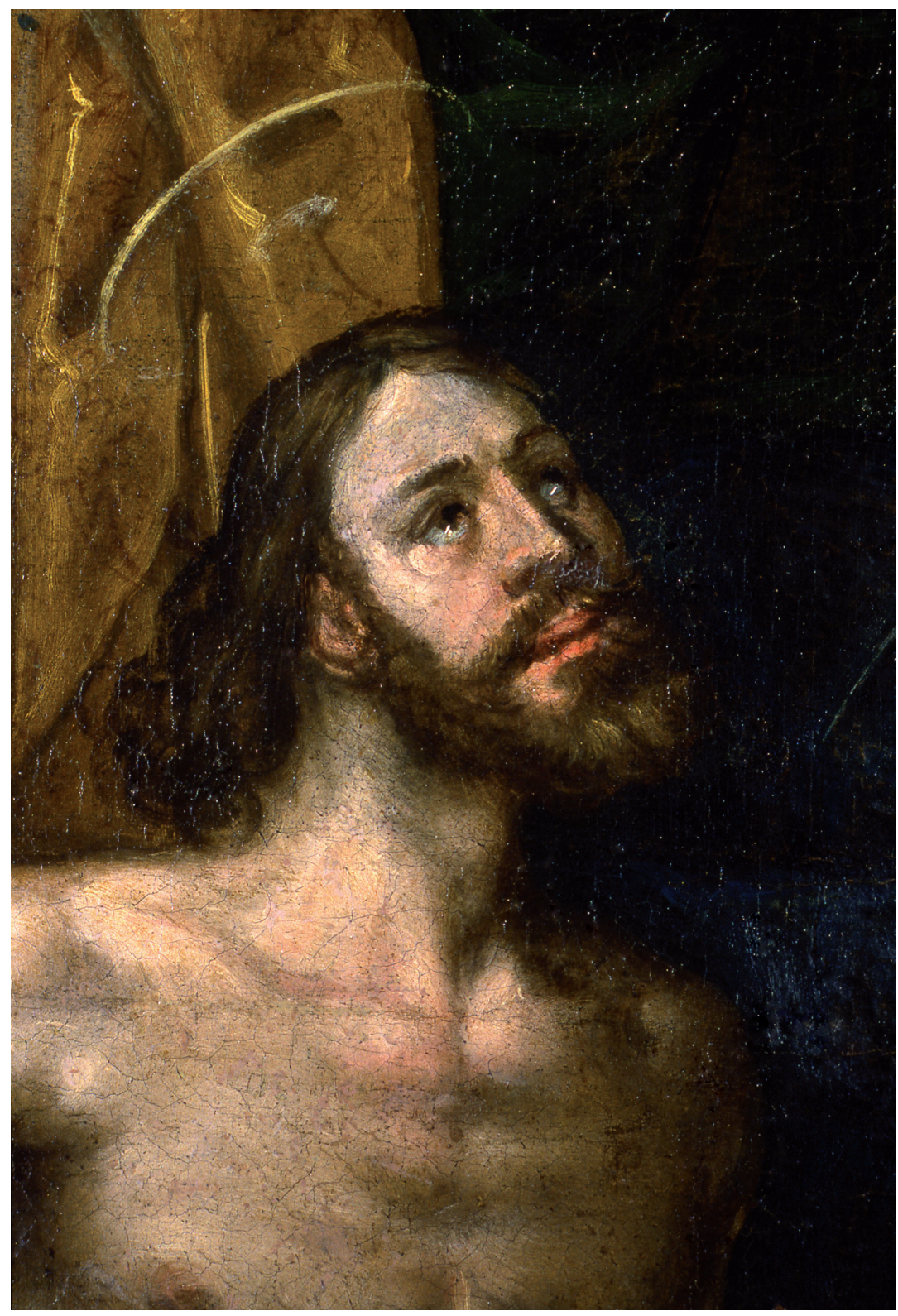

10. Kościół Kamedułów na Bielanach w Krakowie, kaplica Królewska.

Fragment obrazu Św. Władysław biczujacy się.

Około 1635-1636, Tomasz Dolabella. Fot. J. Walczewski. 


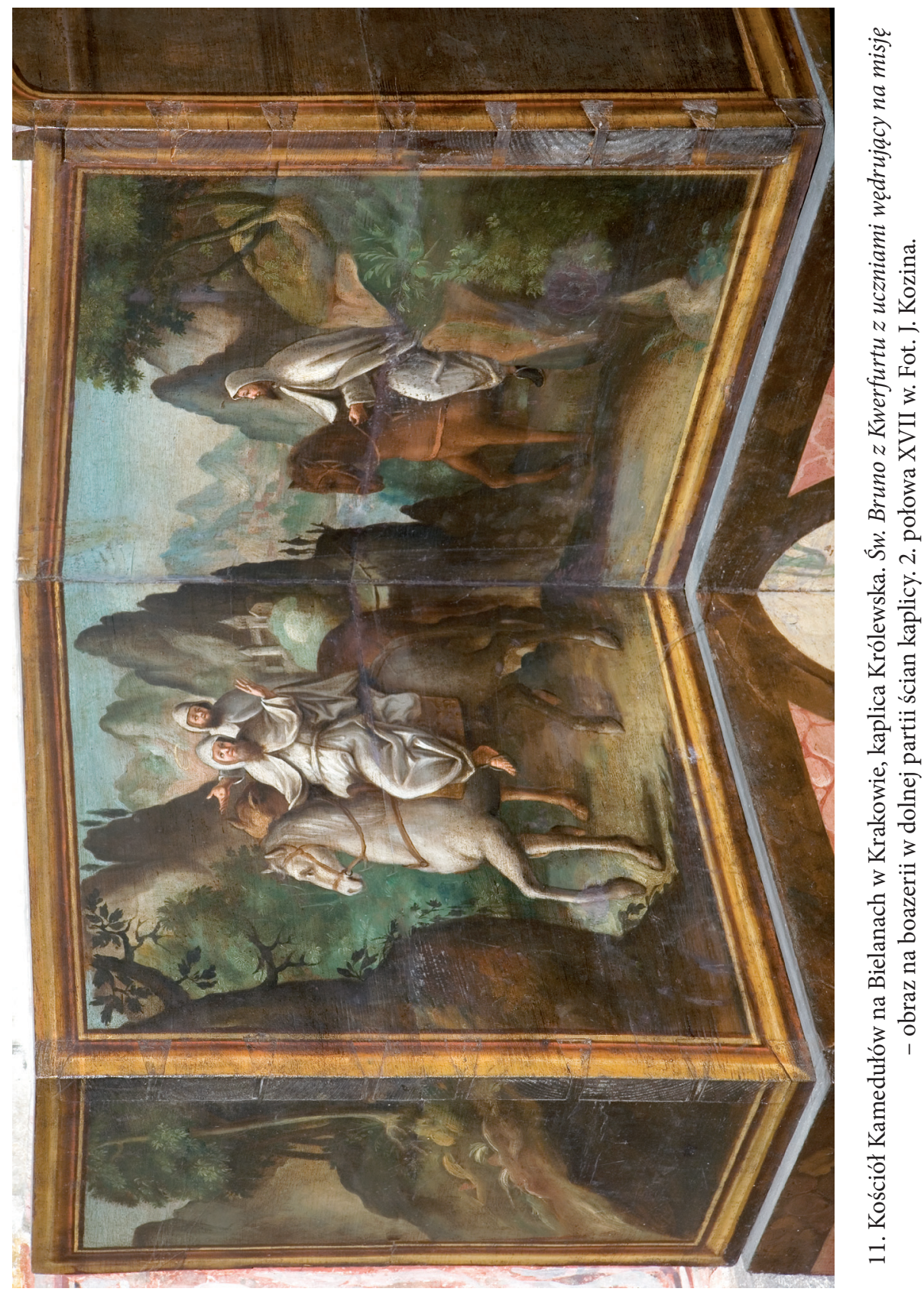




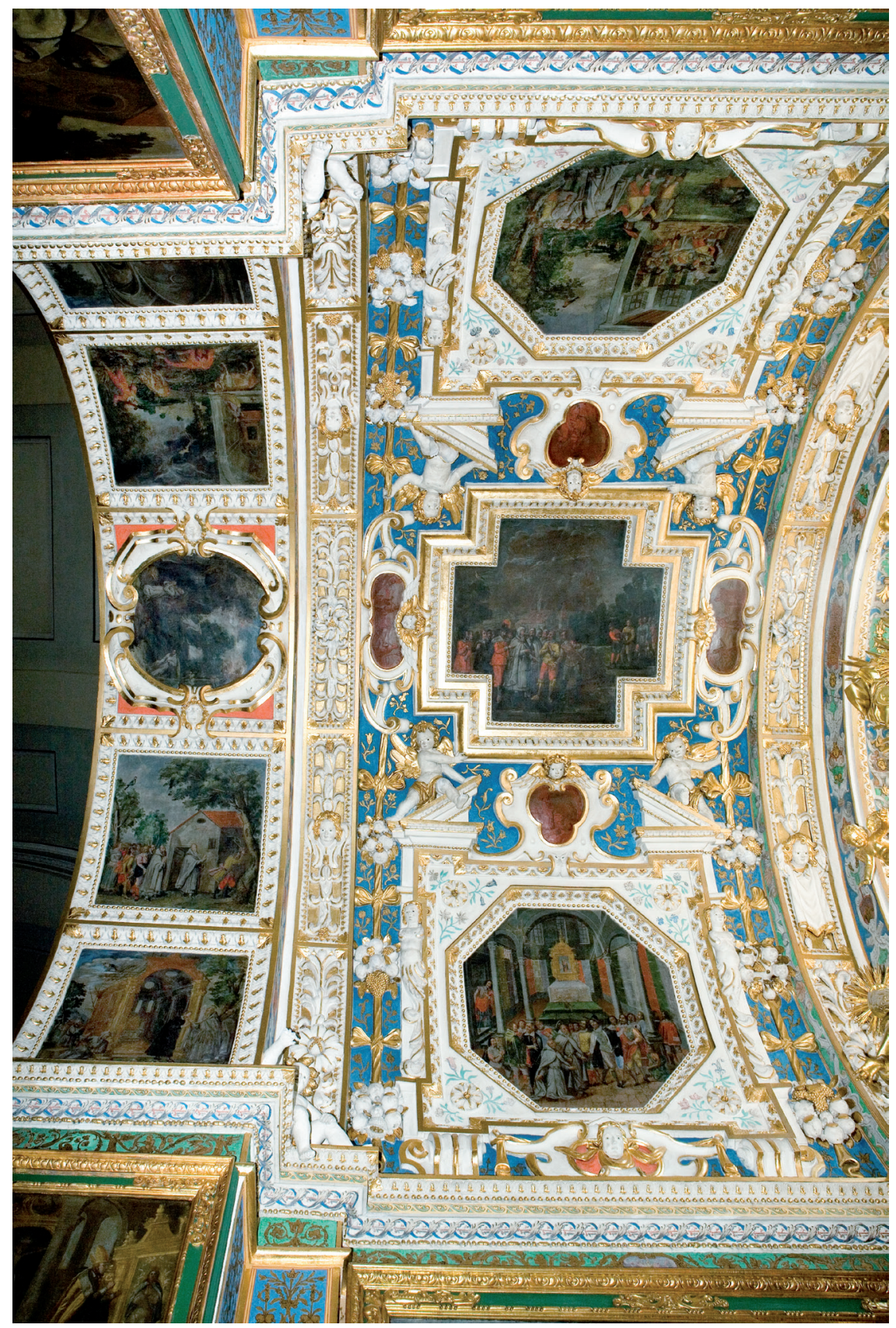

12. Kościół Kamedułów na Bielanach w Krakowie.

Kaplica tzw. Delpacowska fundacji Rafała del Pace - sklepienie arkady i części głównej. Przed 1643. Fot. J. Kozina. 


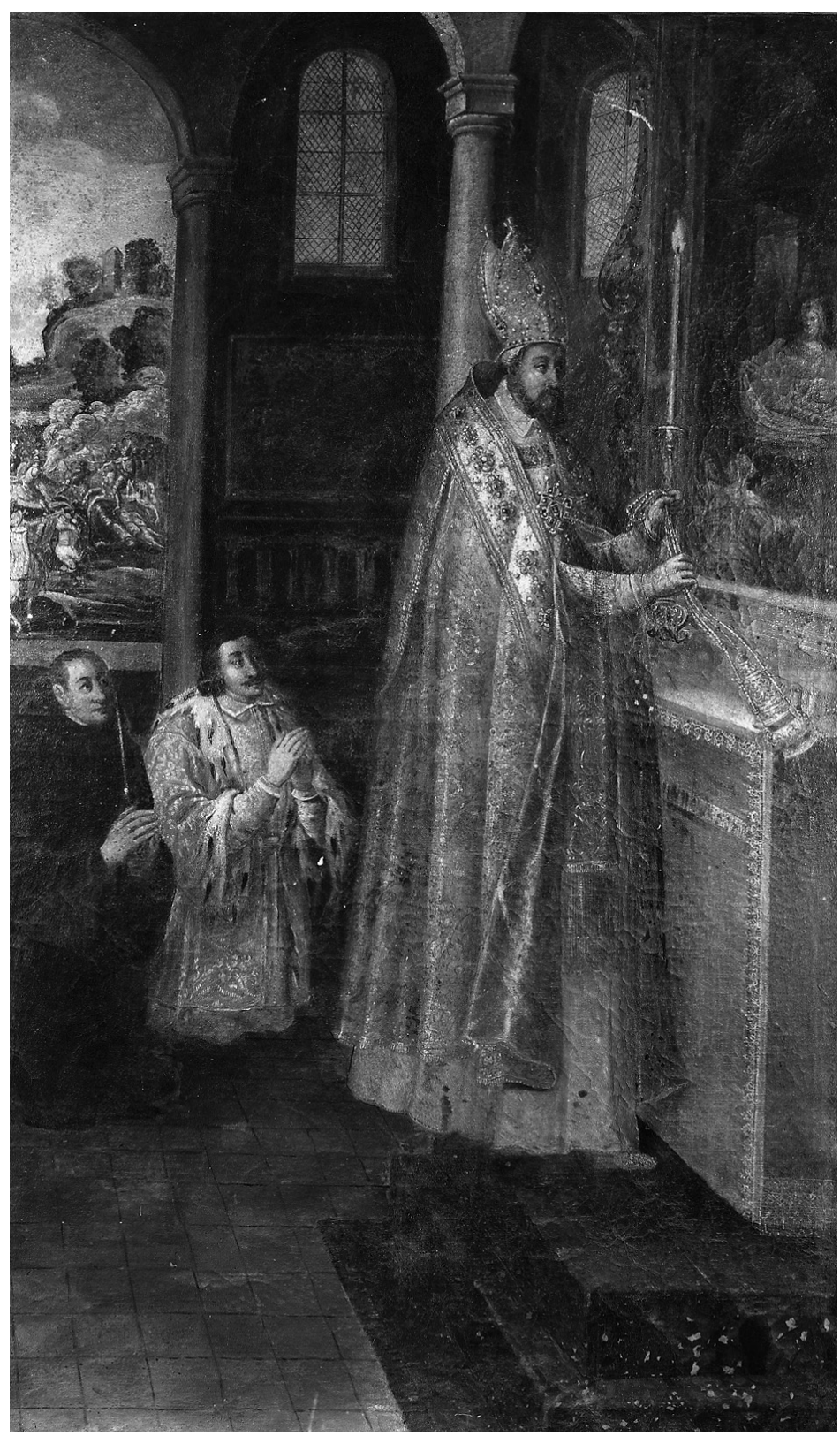

13. Kościół Kamedułów na Bielanach w Krakowie.

Kaplica Delpacowska. Św. Apolinary objawiający się św. Romualdowi

- obraz zawieszony w ościeżach arkady wejściowej prowadzącej do kaplicy, stan przed usunięciem autorskich przemalówek w czasie konserwacji

przeprowadzonej w latach 1960-1962. Przed $1643 \mathrm{r}$. (wg Dokumentacja konserwatorska obrazów Tomasza Dolabelli..., fot. nlb. 7). Fot. K. Nowacki 


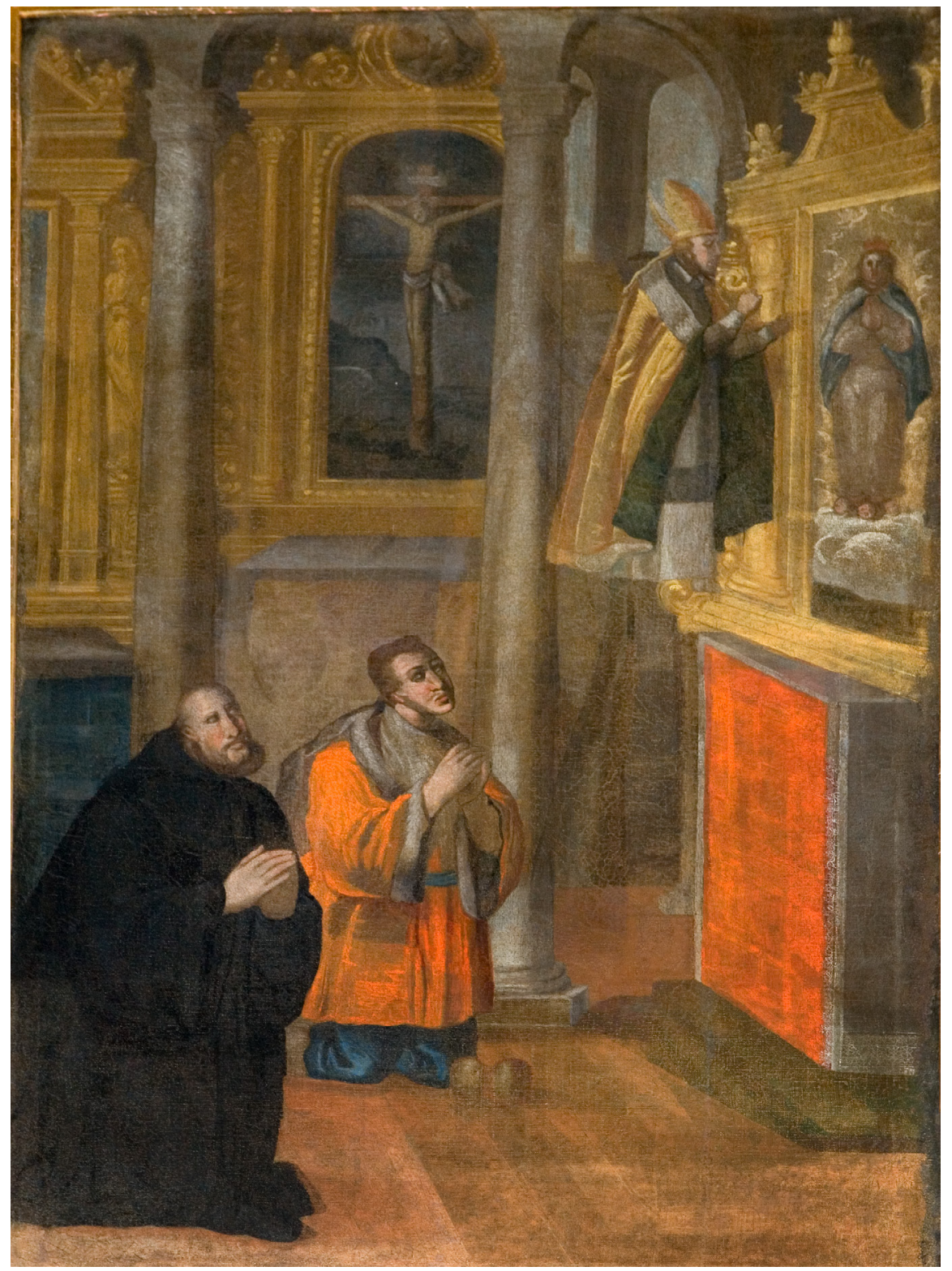

14. Kościół Kamedułów na Bielanach w Krakowie. Kaplica Delpacowska. Fragment obrazu Św. Apolinary objawiający sięśw. Romualdowi - stan obecny. Przed 1643 r. Fot. J. Kozina. 


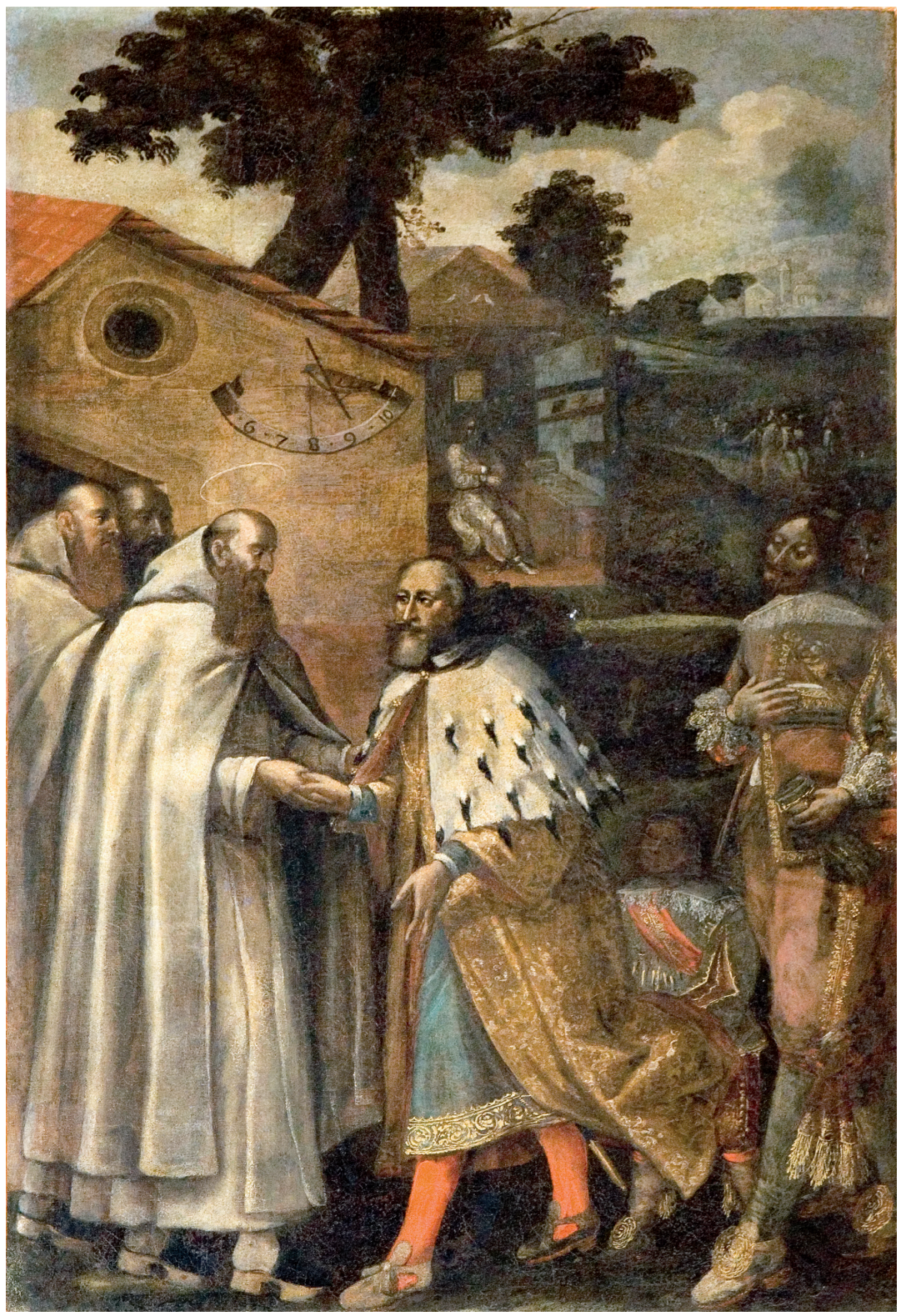

15. Kościół Kamedułów na Bielanach w Krakowie.

Kaplica Delpacowska. Spotkanie św. Romualda z cesarzem Henrykiem II - obraz zawieszony w ościeżach arkady wejściowej prowadzącej do kaplicy, stan obecny. Przed 1643 r. Fot. J. Kozina. 


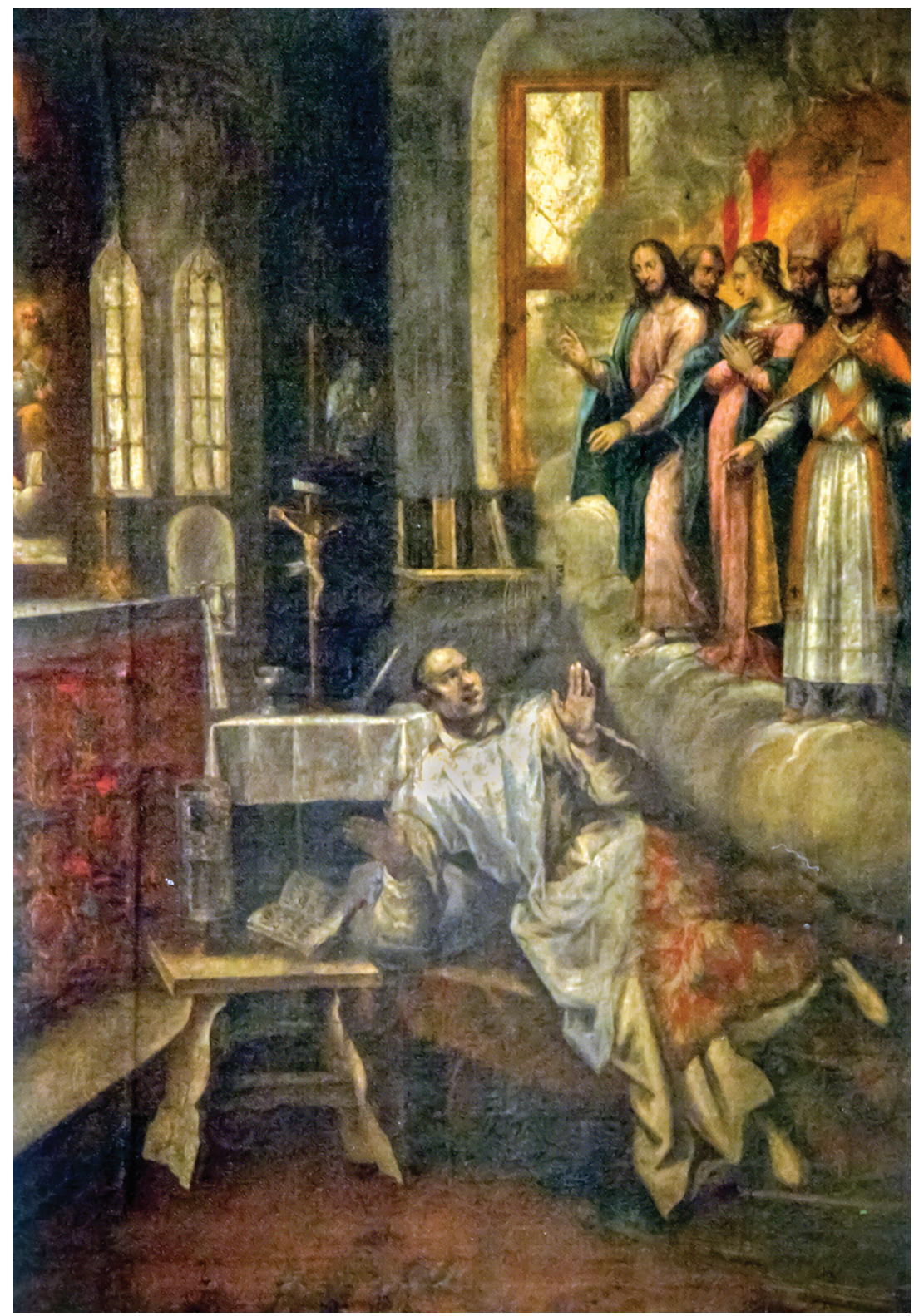

16. Kościół pw. Bożego Ciała, klasztorny kanoników regularnych na Kazimierzu w Krakowie. Śmierć bt. Stanisława Kazimierczyka. 1619 r., Łukasz Porębski. Fot. wg Fabiański, Złoty Kraków..., fot. na s. 103. 


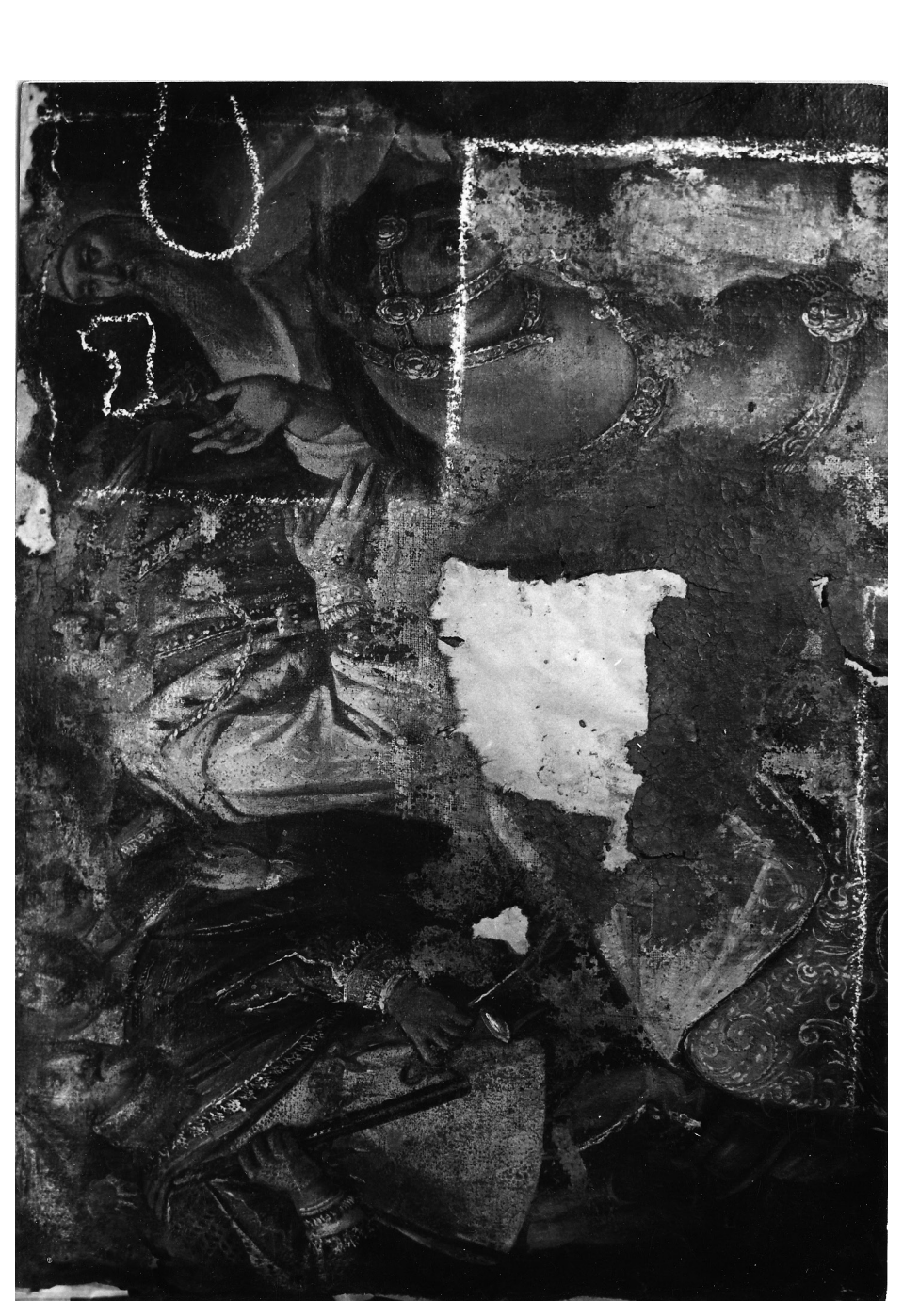

के

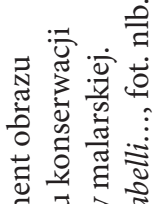

हี

전

政

芯焉离

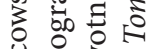

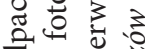

귤

ชั

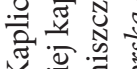

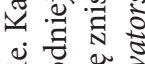

है त्ञ

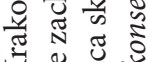

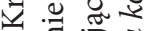

3 . 제

प्ञ

तี जी ई

픈

ㄷำ 1

$\Rightarrow$ 낭

302

율 돈

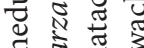

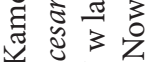

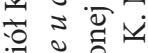

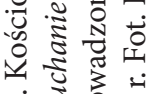

$\therefore \frac{0}{0}$ 范 


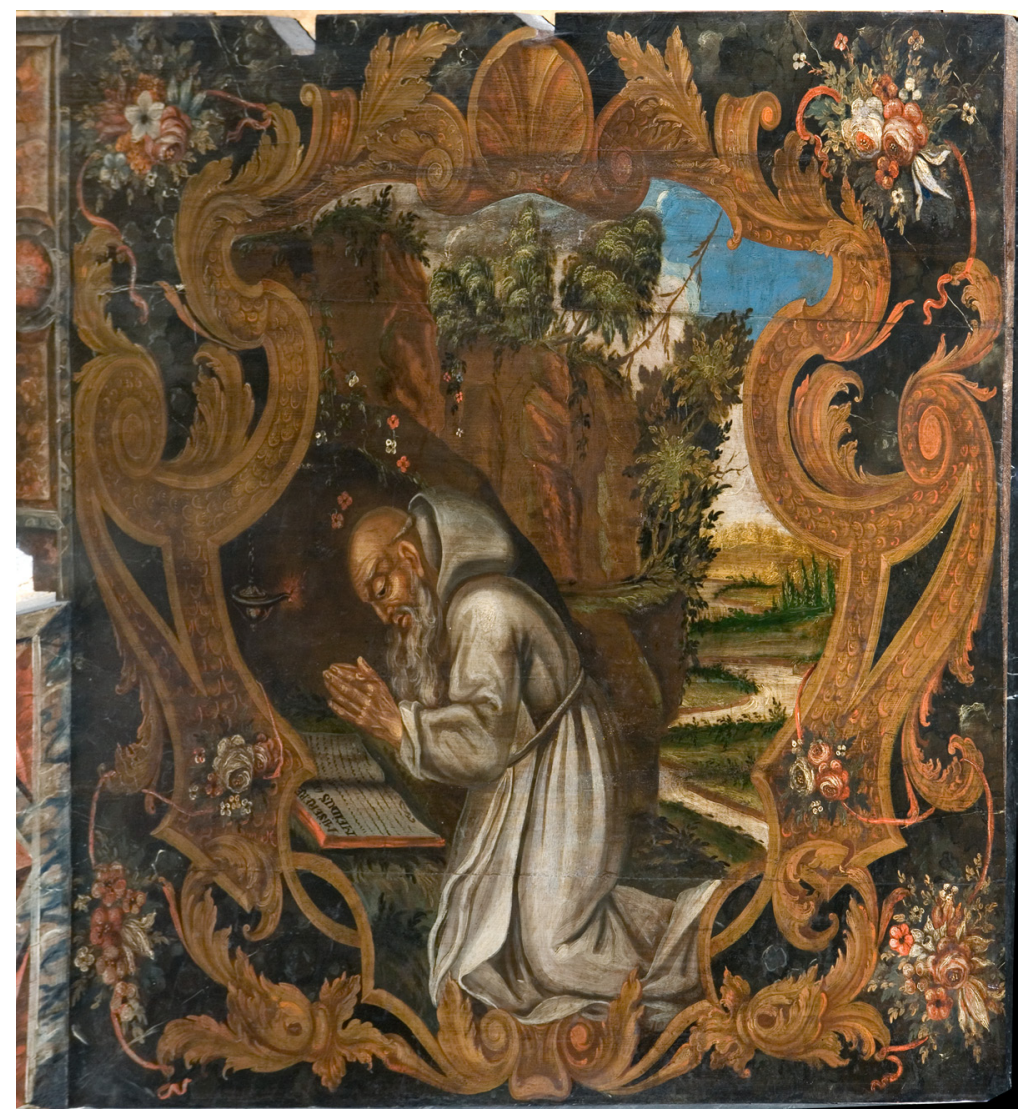

18. Kościół Kamedułów na Bielanach w Krakowie. Kaplica Delpacowska. Pustelnik - obraz na boazerii w dolnej partii ścian kaplicy. Początek XVIII w. Fot. J. Kozina. 